\title{
PRIVATE AND COMMON PROPERTY RIGHTS
}

\author{
Elinor Ostrom and Charlotte Hess \\ Workshop in Political Theory and Policy Analysis, Indiana University \\ (C) 2007 by authors
}

\begin{abstract}
The relative advantages of private property and common property for the efficiency, equity, and sustainability of natural resource use patterns have long been debated in the legal and economics literatures. The debate has been clouded by a troika of confusions that relate to the difference between (1) common-property and open-access regimes, (2) common-pool resources and common-property regimes, and (3) a resource system and the flow of resource units. A property right is an enforceable authority to undertake particular actions in specific domains. The rights of access, withdrawal, management, exclusion, and alienation can be separately assigned to different individuals as well as being viewed as a cumulative scale moving from the minimal right of access through possessing full ownership rights. Some attributes of common-pool resources are conducive to the use of communal proprietorship or ownership and others are conducive to individual rights to withdrawal, management, exclusion and alienation. There are, however, no panaceas! No institutions generate better outcomes for the resource and for the users under all conditions. Many of the lessons learned from the operation of communal property regimes related to natural resource systems are theoretically relevant to understanding of a wide diversity of property regimes that are extensively used in modern societies.

JEL classification: K1, Q2, H4, D7

Keywords: Common Property, Private Property, Common-pool Resources, Governance
\end{abstract}




\section{Introduction}

The issue of the relationship between private property and common property has engaged both legal and economic scholars in a long series of controversies over the meaning, the sequence of development, and the superiority of private vs. common property. The issues debated relate to the efficiency, equity and sustainability of private property as contrasted to common property. The scholarship in both professions has been characterized by formulations that are adopted by each generation of scholars without much effort to examine their foundations or to test them by empirical research. Both have their doctrinal aspects. And, the dominant view in both disciplines has been that private property is clearly superior to common property. Many scholars think of contemporary examples of common property as remnants of the past, likely to disappear during the twenty-first century (see Atran 1993). Recent research, however, has challenged the presumption that private property is necessarily superior to common property.

\section{The legal debate over private vs. common property}

Prior to the publication in 1861 of Ancient Law by the distinguished English jurist, Henry Sumner Maine, the accepted view among Western jurists was that the origin of the concept of property in ancient times was the occupation of land by a single proprietor and his family (Grossi 1981). Further, the superiority of individual property holdings was so well accepted in the legal literature of the early nineteenth century that the possibility of other forms of property existing on the European continent threatened juridical views about the origins of social order. Maine drew not only on his own extensive research in India but also on the work of Georg Ludwig von Maurer $(1854,1856)$ on the primitive Germanic village communities, the Mark, and 
of the pioneering work of William Blackstone (1766). Maine concluded that: 'it is more than likely that joint ownership, and not separate ownership, is the really archaic institution, and that the forms of property that will afford us instruction will be those that are associated with the rights of families and of groups of kindred' ([1861] 1963, p. 252). This set off a flurry of publications challenging and supporting his conclusion (see extensive bibliographic citations in Grossi 1981). The great debate had much more than academic importance, as major political struggles continued throughout the nineteenth century over the status of the many remaining forms of common property on the European continent. A legal and political belief system that saw the origin of property itself in the efforts of individual proprietors to occupy land gave the landed proprietor a special role in society. These beliefs helped to justify the passage of legislation to eliminate collective landholding rights and to authorize enclosures and the takeover of communal properties by individual proprietors.

The meaning of private property in comparison to common property remains a contested issue in modern legal scholarship. Ellickson, Rose, and Ackerman (1995), for example, start their recent textbook on property law with a first chapter devoted to 'The Debate over Private Property'. The second chapter addresses 'The Problem of the Commons'. In the latter chapter, they include parts of the famous article by Hardin (1968) on 'The Tragedy of the Commons', but then ask students the following questions: 'Private property is often said to avert the tragedy of the commons. But does it? Who enforces property limitations? Does another kind of "commons” problem lurk in the organization and maintenance of a property regime?'(Ellickson, Rose, and Ackerman 1995, p. 141). In an earlier volume, Rose (1994, p. 37) points to the 'kicker' in a sharp distinction between private and common property when she 
stresses that a private-property regime as a system 'has the same structure as a common property’ (see also Epstein 1979, 1994, 2002).

\section{The economic debate over private vs. common property}

Economists tend to view common-property institutions as having a longer history than private-property institutions and to explain the growth of modern, Western societies in part as the result of changing from common property to private property (North and Thomas 1976; North, Anderson, and Hill 1983). Private property is considered by most economists to be an essential ingredient in economic development due to the incentives associated with diverse kinds of property relationships (see, for example, Welch 1983). A farmer who owns his own labor, land and other factor inputs, for example, is likely to see a direct relationship between investments and the level of benefit achieved over the long term. A farmer who belongs to an agricultural production cooperative, on the other hand, may see only a loose connection between personal contributions and benefits. The more individuals in a society whose work is only loosely connected to their benefits, the more pervasive an attitude of free riding can become. If everyone tends to free ride on the work of others, overall economic productivity will be low.

Private-property rights, however, cannot simply emerge spontaneously from a common-property system. Private-property rights depend upon the existence and enforcement of a set of rules that define who has a right to undertake which activities on their own initiative and how the returns from that activity will be allocated (V. Ostrom 2008). In other words, rules and rulers are required to establish, monitor and enforce a property system. While some rules generate incentives that greatly increase the welfare of most participants in an economy, there are always individuals who 
resist changes because of benefits they receive from a prior system or propose changes that particularly benefit themselves. Rulers may also receive substantial returns from making rules that benefit some to the detriment of others. Thus, rentseeking behavior is expected on the part of both entrepreneurs and rulers.

Common-property regimes are, therefore, presumed by many economists to be inefficient due to three problems. One is rent dissipation, because no one owns the products of a resource until they are captured, and everyone engages in an unproductive race to capture these products before others do (Knight 1924; Gordon 1954; Scott 1955; Schaefer 1957; Cheung 1970; C. Clark 1976, 1980; Dasgupta and Heal 1979). The second is the high transaction and enforcement costs expected if communal owners were to try to devise rules to reduce the externalities of their mutual overuse (Demsetz 1967; Coase 1960). The third is low productivity, because no one has an incentive to work hard in order to increase their private returns (North 1990). Common-property regimes are presumably retained by rulers who do not understand the enhancement in overall economic welfare that will result from a change to private property or who are supported by those who benefit from these ‘archaic’ regimes. A common policy prescription is articulated by R. Smith (1981, p. 467) when he stated that 'the only way to avoid the tragedy of the commons in natural resources and wildlife is to end the common-property system by creating a system of private property rights'.

\section{Confusions that generate misunderstanding}

The debate about the relative merits of private and common property has been clouded by a troika of confusions that hinder scholarly communication. Different meanings are assigned to terms without clarifying how multiple aspects relate to one 
another. The source of confusion relates to the differences between (1) commonproperty and open-access regimes, (2) common-pool resources and common-property regimes, and (3) a resource system and the flow of resource units. All three sources of confusion reduce clarity in assigning meaning to terms and retard theoretical and empirical progress.

The confusion between common-property and open-access regimes In a now classic article, Ciriacy-Wantrup and Bishop (1975) clearly demarked the difference between property regimes that are open access, where no one has the legal right to exclude anyone from using a resource, from common property, where the members of a clearly demarked group have a legal right to exclude nonmembers of that group from using a resource (see also Bromley 1991). Open-access regimes (로 nullius) — including the classic cases of the open seas and the atmosphere-have long been considered in legal doctrine as involving no limits on who is authorized to use a resource. If anyone can use a resource, no one has an incentive to conserve their use or to invest in improvements. If such a resource generates highly valued products, then one can expect that the lack of rules regarding authorized use will lead to misuse and overconsumption. Some local grazing areas, inshore fisheries and forests are effectively open-access resources, but many fewer than presumed in the literature.

Some open-access regimes lack effective rules defining property rights by default (Dales 1968). Either the resources affected by these open-access regimes are not contained within a nation-state or no entity has successfully laid claim to legitimate ownership. Other open-access regimes are the consequence of conscious public policies to guarantee the access of all citizens to the use of a resource within a political jurisdiction. The concept of jus publicum applies to their formal status, but 
effectively these resources are open access. The state governments of Oregon and Washington intervened in the early twentieth century to prevent local salmon fishermen from devising rules that would have limited entry and established harvesting limits (Higgs 1996). Fishing unions along the US coastal areas tried to organize inshore fisheries so as to limit entry and establish harvesting limits during the 1950s. Even though their efforts could not have had a serious impact on prices due to the presence of an active international market for fish, the fishing unions were prosecuted by the US Department of Justice and found in violation of the Sherman Antitrust Act (Johnson and Libecap 1982). Thus, US inshore fisheries have effectively been open-access resources during much of the twentieth century as a result of governmental action to prevent local fishing groups from establishing forms of common-property regimes within those political jurisdictions. In more recent times, however, both the national and state governments have reversed their prior stands and have actively sought ways of creating forms of co-management in inshore fisheries (see Pinkerton 1989, 1994; Acheson 2003; Wilson, Yan, and Wilson 2007).

A third type of open-access regime results from the ineffective exclusion of nonowners by the entity assigned formal rights of ownership. In many developing countries, the earlier confusion between open-access and common-property regimes paradoxically led to an increase in the number and extent of local resources that are effectively open access. Common-property regimes controlling access and harvesting from local streams, forests, grazing areas, and inshore fisheries had evolved over long periods of time in all parts of the world, but were rarely given formal status in the legal codes of newly independent countries (Wiersma 2005).

As concern for the protection of natural resources mounted during the 1960s, many developing countries nationalized all land and water resources that had not yet 
been recorded as private property. The institutional arrangements that local users had devised to limit entry and use lost their legal standing, but the national governments lacked monetary resources and personnel to monitor the use of these resources effectively. Thus, resources that had been under a de facto common-property regime enforced by local users were converted to a de jure government-property regime, but reverted to a de facto open-access regime. When resources that were previously controlled by local participants have been nationalized, state control has usually proved to be less effective and efficient than control by those directly affected, if not disastrous in its consequences (Curtis 1991; Hilton 1992; Panayotou and Ashton 1992; Ascher 1995). The harmful effects of nationalizing forests that had earlier been governed by local user groups have been well documented for Thailand (Feeny 1988), Niger (Thomson 1977; Thomson, Feeny, and Oakerson 1992), Nepal (Arnold and Campbell 1986; Messerschmidt 1986), and India (Gadgil and Iyer 1989; Jodha 1990). Similar results have occurred in regard to inshore fisheries taken over by state or national agencies from local control by the inshore fishermen themselves (Cordell and McKean 1992; Cruz 1986; Dasgupta 1982; Higgs 1996; Pinkerton 1989).

\section{The confusion between a resource system and a property regime}

The problems resulting from confusing open-access regimes with common-property regimes are particularly difficult to overcome due to a second terminological problem. The term 'common-property resource' is frequently used to describe a type of economic good that is better referred to as a 'common-pool resource'. All commonpool resources share two attributes of importance for economic activities: (1) it is costly to exclude individuals from using the good either through physical barriers or legal instruments and (2) the benefits consumed by one individual subtract from the 
benefits available to others (V. Ostrom and E. Ostrom 1977b; E. Ostrom, Gardner, and Walker 1994). Recognizing a class of goods that shares these two attributes enables scholars to identify the core theoretical problems facing individuals whenever more than one individual or group utilizes such resources for an extended period of time. Using 'property' in the term used to refer to a type of good, reinforces the impression that goods sharing these attributes tend everywhere to share the same property regime.

Common-pool resources share with public goods the difficulty of developing physical or institutional means of excluding beneficiaries. Unless means are devised to keep nonauthorized users from benefiting, the strong temptation to free ride on the efforts of others will lead to a suboptimal investment in improving the resource, monitoring use, and sanctioning rule-breaking behavior. Second, the products or resource units from common-pool resources share with private goods the attribute that one person's consumption subtracts from the quantity available to others. Thus, common-pool resources are subject to problems of congestion, overuse and potential destruction unless harvesting or use limits are devised and enforced. In addition to sharing these two attributes, particular common-pool resources differ on many other attributes that affect their economic usefulness including their size, shape and productivity and the value, timing and regularity of the resource units produced.

Common-pool resources may be owned by national, regional, or local governments; by communal groups; by private individuals or corporations; or used as open access resources by whomever can gain access. Each of the broad types of property regimes has different sets of advantages and disadvantages, but at times may rely upon similar operational rules regarding access and use of a resource (Feeny et al. 1990). Examples exist of both successful and unsuccessful efforts to govern and 
manage common-pool resources by governments, communal groups, cooperatives, voluntary associations, and private individuals or firms (Bromley et al. 1992; K. Singh 1994; K. Singh and Ballabh 1996). Thus, as discussed below, there is no automatic association of common-pool resources with common-property regimes— $\underline{\text { or, }}$ with any other particular type of property regime. Further, common-property arrangements are essentially share contracts (Lueck 1994; Eggertsson 1990, 1992, 1993) and, as such, face similar problems of potential opportunistic behavior and moral hazard problems.

The confusion between the resource and the flow of resource units Common-pool resources are composed of resource systems and a flow of resource units or benefits from these systems (Blomquist and Ostrom 1985). The resource system (or alternatively, the stock or the facility) is what generates a flow of resource units or benefits over time (Lueck 1995). Examples of typical common-pool resource systems include lakes, rivers, irrigation systems, groundwater basins, forests, fishery stocks and grazing areas. Common-pool resources may also be facilities that are constructed for joint use, such as mainframe computers and the Internet. The resource units or benefits from a common-pool resource include water, timber, medicinal plants, fish, fodder, central processing units, and connection time. Devising property regimes that effectively allow sustainable use of a common-pool resource requires rules that limit access to the resource system and other rules that limit the amount, timing, and technology used to withdraw diverse resource units from the resource system. 


\section{Property as bundles of rights}

A property right is an enforceable authority to undertake particular actions in a specific domain (Commons 1968). Property rights define actions that individuals can take in relation to other individuals regarding some 'thing'. If one individual has a right, someone else has a commensurate duty to observe that right. Schlager and Ostrom (1992) identify five property rights that are most relevant for the use of common-pool resources, including access, withdrawal, management, exclusion, and alienation. These are defined as:

Access: $\quad$ The right to enter a defined physical area and enjoy nonsubtractive benefits (for example, hike, canoe, sit in the sun).

Withdrawal: The right to obtain resource units or products of a resource system (for example, catch fish, divert water).

Management: The right to regulate internal use patterns and transform the resource by making improvements.

Exclusion: The right to determine who will have access rights and withdrawal rights, and how those rights may be transferred.

Alienation: The right to sell or lease management and exclusion rights (Schlager and Ostrom 1992).

In much of the economics literature, private property is defined as equivalent to alienation. Property-rights systems that do not contain the right of alienation are considered to be ill-defined. Further, they are presumed to lead to inefficiency since property-rights holders cannot trade their interest in an improved resource system for other resources, nor can someone who has a more efficient use of a resource system purchase that system in whole or in part (Demsetz 1967). Consequently, it is assumed 
that property-rights systems that include the right to alienation will be transferred to their highest valued use. Larson and Bromley (1990) challenge this commonly held view and show that much more information must be known about the specific values of a large number of parameters before judgments can be made concerning the efficiency of a particular type of property right.

Instead of focusing on one right from the bundle, it is more useful to classify five types of property-rights holders as shown in Table 1 . In this view, individuals or collectivities may hold well-defined property rights that include or do not include all five of the rights defined above. This approach separates the question of whether a particular right is well-defined from the question of the effect of having a particular set of rights. 'Authorized entrants' include most recreational users of national parks who purchase an operational right to enter and enjoy the natural beauty of the park, but do not have a right to harvest forest products. Those who have both entry and withdrawal use-right units are 'authorized users'. The presence or absence of constraints upon the timing, technology used, purpose of use and quantity of resource units harvested are determined by operational rules devised by those holding the collective-choice rights (or authority) of management and exclusion.

(Table 1 about here)

The operational rights of entry and use may be finely divided into quite specific ‘tenure niches’ (Bruce 1995) that vary by season, by use, by technology, and by space. Tenure niches may overlap when one set of users owns the right to harvest fruits from trees, another set of users owns the right to the timber in these trees, and the trees may be located on land owned by still others (Bruce, Fortmann, and Nhira 1993). Operational rules may allow authorized users to transfer access and withdrawal 
rights either temporarily through a rental agreement, or permanently when these rights are assigned or sold to others.

'Claimants' possess the operational rights of access and withdrawal plus a collective-choice right of managing a resource that includes decisions concerning the construction and maintenance of facilities and the authority to devise limits on withdrawal rights. The net fishers of Jambudwip, India, for example, annually regulate the positioning of nets so as to avoid interference, but do not have the right to determine who may fish along the coast (Raychaudhuri 1980). Fishing territories are a frequent form of property for indigenous, inshore fishers (Durrenberger and Palsson 1987). Farmers on large-scale government irrigation systems frequently devise rotation schemes for allocating water on a branch canal (Benjamin et al. 1994; Shivakoti and Ostrom 2002).

'Proprietors' hold the same rights as claimants with the addition of the right to determine who may access and harvest from a resource. Most of the property systems that are called 'common-property' regimes involve participants who are proprietors and have four of the above rights, but do not possess the right to sell their management and exclusion rights even though they most frequently have the right to bequeath it to members of their family and to earn income from the resource (see Berkes 1989; Bromley et al. 1992; McCay and Acheson 1987; McCarthy 2006).

Empirical studies have found that some proprietors have sufficient rights to make decisions that promote long-term investment and harvesting from a resource. Place and Hazell (1993) conducted surveys in Ghana, Kenya, and Rwanda to ascertain if indigenous land-rights systems were a constraint on agricultural productivity. They found that having the rights of a proprietor as contrasted to an owner in these settings did not affect investment decisions and productivity. Other studies conducted in 
Africa (Migot-Adholla et al. 1991; Bruce and Migot-Adholla 1994) also found little difference in productivity, investment levels, or access to credit. In densely settled regions, however, proprietorship over agricultural land may not be sufficient (Feder et al. 1988; Feder and Feeny 1991; Anderson and Lueck 1992). As land is densely settled, the absence of a title reduces the options for farmers to sell their land and reap a return on this asset. Further, without a title, farmers lack collateral to obtain credit to invest more intensively in the productive potential of their land (see Alston, Libecap, and Schneider 1996).

Thus, a key finding from an overview of many studies is that no type of property-rights regime works equivalently in all types of settings (Quinn et al. 2007). For private-property systems in land to make a difference in productivity gains, one probably needs (1) a somewhat dense population so competition for use is present and (2) the existence of effective markets related to credit, inputs, and the sale of commodities (see further discussion in Section 7). In a series of studies of inshore fisheries, self-organized irrigation systems, forest user groups and groundwater institutions, proprietors tended to develop clear boundary rules to exclude noncontributors; established authority rules to allocate withdrawal rights; devised methods for monitoring conformance; and used graduated sanctions against those who do not conform to these rules (Blomquist 1992; Tang 1994; Lam 1998; T. Yandle 2003; Weinstein 2000).

'Owners' possess the right of alienation - the right to transfer a good in any way the owner wishes that does not harm the physical attributes or uses of other owners - in addition to the bundle of rights held by a proprietor. An individual, a private corporation, a government, or a communal group may possess full ownership rights to any kind of good including a common-pool resource (Montias 1976). The 
rights of owners, however, are never absolute. Even private owners have responsibilities not to generate particular kinds of harms for others (Demsetz 1967).

What should be obvious by now is that the world of property rights is far more complex than simply government, private and common property. These terms better reflect the status and organization of the holder of a particular right than the bundle of property rights held. All of the above rights can be held by single individuals or by collectivities. Some communal fishing systems grant their members all five of the above rights, including the right of alienation (Miller 1989). Members in these communal fishing systems have full ownership rights. Similarly, farmer-managed irrigation systems in Nepal, the Philippines and Spain have established transferable shares to the systems. Access, withdrawal, voting and maintenance responsibilities are allocated by the amount of shares owned (Maass and Anderson 1986; Martin 1986; Siy 1982). On the other hand, some proposals to 'privatize' inshore fisheries through the devise of an Individual Transferable Quota (ITQ), allocate transferable use rights to authorized fishers but do not allocate rights related to the management of the fisheries, the determination of who is a participant, nor the transfer of management and exclusion rights. Thus, proposals to establish ITQ systems, which are frequently referred to as forms of 'privatization', do not involve full ownership.

With new commons, such as the Internet, the bundle may include other types of rights. Hess and Ostrom (2007, pp. 52-53) found that electronic information resources often have more than five types of rights. Drawing on Schlager and Ostrom (1992), seven major types of property rights were identified. The following rights are defined for an online institutional repository. 
Access The right to enter a defined physical area and enjoy nonsubtractive benefits.

Contribution The right to contribute to the content.

Extraction The right to obtain resource units or products of a resource system.

Removal The right to remove one's artifacts from the resource.

Management/ The right to regulate internal use patterns and transform the resource Participation by making improvements.

Exclusion The right to determine who will have access, contribution, extraction, and removal rights and how those rights may be transferred.

Alienation The right to sell or lease management and exclusion rights.

Other examples are the Creative Commons (CC) licenses that were established to allow authors to different rights for their works rather than the 'one size fits all' standard copyright agreement. CC defines the spectrum of possibilities between full copyright—all rights reserved_—and the public domain— no rights reserved. Rights given to users by the authors are Attribution, Noncommercial, No derivative works and Share alike (see http://creativecommons.org/about/license/).

The next two sections are devoted to a discussion of the attributes of commonpool resources that are conducive to communal proprietorship or communal ownership as contrasted to individual ownership. Groups of individuals are considered to share communal property rights when they have formed an organization that exercises at least the collective-choice rights of management and exclusion in relationship to some defined resource system and the resource units produced by that system. Where communal groups are full owners, members of the group have the further right to sell their access, use, exclusion and management rights to others, subject in many systems to the approval of the other members of the group. Some 
communal proprietorships are formally organized and recognized by legal authorities as having a corporate existence that entails the right to sue and be sued, the right to hold financial assets in a common bank account, and to make decisions that are binding on members. Other communal proprietorships are less formally organized and may exercise de facto property rights that may or may not be supported by legal authorities if challenged by nonmembers. Obviously, such groups hold less welldefined bundles of property rights than those who are secure in their de jure rights even though the latter may not hold the complete set of property rights defined as full ownership. In other words, well-defined and secure property rights may not involve the right to alienation.

\section{Attributes of common-pool resources conducive to the use of communal proprietorship or ownership}

Even though all common-pool resources share the difficulty of devising methods to achieve exclusion and a sustainable level of harvesting of resource units, the variability of common-pool resources is immense in regard to other attributes that affect the incentives of resource users and the likelihood of achieving outcomes that approach optimality. Further, whether it is difficult or costly to develop physical or institutional means to exclude nonbeneficiaries depends on the availability and cost of technical and institutional solutions to the problem of exclusion and the relationship of the cost of these solutions to the expected benefits of achieving exclusion from a particular resource.

Let us start initially with a discussion of land as a resource system. Where population density is extremely low, land is abundant, and land generates a rich diversity of plant and animal products without much husbandry, the expected costs of establishing and defending boundaries to a parcel of land of any size may be greater 
than the expected benefits of enclosure (Demsetz 1967; Feeny 1993). Settlers moving into a new terrain characterized by high risk due to danger from others, from a harsh environment, or from lack of appropriate knowledge, may decide to develop one large, common parcel prior to any divisions into smaller parcels (Ellickson 1993). Once land becomes scarce, conflict over who has the rights to invest in improvements and reap the results of their efforts can lead individuals to want to enclose land through fencing or institutional means to protect their investments. There are tradeoffs in costs to be considered, however. The more land included within one enclosure, the lower the costs of defending all the boundaries, but the higher the costs of regulating the use of the enclosed parcel.

The decision to enclose may be taken by the joint owners to divide the commons into a series of private plots owned exclusively by single families (Field 1984, 1985, 1989; Ellickson 1993). The benefits of enclosing land depend on the scale of productive activity involved. For some agricultural activities, as discussed below, there may be considerable benefits associated with smaller parcels fully owned by a family enterprise. For other activities, the benefits may not be substantial. Moving all the way to private plots is an efficient move when the expected marginal returns from enclosing numerous plots exceed the expected marginal costs of defending a much more extended system of boundaries and the reduced transaction costs of making decisions about use patterns (Nugent and Sanchez 1989).

In a classic study of the diversity of property-rights systems used for many centuries by Swiss peasants, Netting $(1976,1981)$ observed that the same individuals fully divided their agricultural land into separate family-owned parcels, but that grazing lands located on the Alpine hillsides were organized into communal property systems. In these mountain valleys, the same individuals used different property- 
rights systems side-by-side for multiple centuries. Each local community had considerable autonomy to change local rules, so there was no problem of someone else imposing an inefficient set of rules on them. Netting argued that attributes of the resource affected which property-rights systems were most likely for diverse purposes. Netting identified five attributes that he considered to be most conducive to the development of communal property rights:

1. low value of production per unit of area;

2. high variance in the availability of resource units on any one parcel;

3. low returns from intensification of investment;

4. substantial economies of scale by utilizing a large area; and

5. substantial economies of scale in building infrastructures.

Steep land where rainfall is scattered may not be suitable for most agricultural purposes, but can be excellent land for pasture and forests if aggregated into sufficiently large parcels. By developing communal property rights to large parcels of such land, those who are members of the community are able to share environmental risks due to the unpredictability of rain-induced growth of grasses within any smaller region. Further, herding and processing of milk products is subject to substantial economies of scale. If individual families develop means to share these reduced costs, all can save substantially (Agrawal 1999). Building the appropriate roads, retaining walls and processing facilities may also be done more economically if these efforts are shared.

While the Swiss peasants were able to devote these harsh lands to productive activities, they had to invest time and effort in the development of rules that would reduce the incentives to overgraze and would ensure that investments in shared infrastructure were maintained over time. In many Swiss villages, rights to common 
pasturage were distributed according to the number of cows that could be carried over the winter using hay supplies produced on the owners' private parcels. In all cases, the village determined who had use rights, what the specific access and withdrawal rights were, how investment and maintenance costs were to be shared, and how the annual returns from common processing activities were to be shared. All of these systems included at least village proprietorship rights, but some Swiss villages developed full ownership rights by incorporating and authorizing the buying and selling of shares (usually with the approval of the village). Netting's findings are strongly supported by studies of mountain villages in Japan, where thousands of rural villages have held communal property rights to extensive forests and grazing areas located in the steep mountainous regions located above their private agricultural plots (McKean 1982, 1992a, 1992b). Similar systems have existed in Norway for centuries (Ørebech et al. 2005; Sandberg 1998).

The importance of sharing risk is stressed in other theoretical and empirical studies of communal proprietorships (Gupta 1986; Nugent and Sanchez 1993). Unpredictability and risk are increased in systems where resource units are mobile and where storage facilities, such as dams, do not exist (Schlager, Blomquist, and Tang 1994). Institutional facilities for sharing risk, such as formal insurance systems or institutionalized mechanisms for reciprocal obligations in times of plenty, also affect the kinds of property-rights systems that individuals can devise. When no physical or institutional mechanisms exist for sharing risk, communal property arrangements may enable individuals to adopt productive activities not feasible under individual property rights. In the Sudan, for instance, the variance in the productivity of land over space — due largely to the fluctuation in rainfall from year to year-is strongly associated with the size of communally held parcels allocated to grazing 
(Nugent and Sanchez 1993). Ellickson (1993) compares the types of environmental and personal security risks faced by new settlers in New England, in Bermuda, and in Utah to explain the variance in the speed of converting jointly held land to individually held land in each of these settlements.

A consistent finding across many studies of communal property-rights systems is that these systems do not exist in isolation and are usually used in conjunction with individual ownership. In most irrigation systems that are built and managed by the farmers themselves, for example, each farmer owns his or her own plot(s) while participating as a joint proprietor or owner in a communally organized irrigation system (Coward 1980; Sengupta 1991, 1993; Tang 1992; Vincent 1995; Wade 1992). Water is allocated to individual participants using a variety of individually tailored rules, but those irrigation systems that have survived for long periods of time tend to allocate water and responsibilities for joint costs using a similar metric-frequently the amount of land owned by a farmer (E. Ostrom 1990, 1992). In other words, benefits are roughly proportional to the costs of investing and maintaining the system itself.

Further, formally recognized communal systems are usually nested into a series of governance units that complement the organizational skills and knowledge of those involved in making collective-choice decisions in smaller units (O. Johnson 1972). Since the Middle Ages, most of the Alpine systems in both Switzerland and Italy have been nested in a series of self-governing communities that respectively governed villages, valleys, and federations of valleys (Merlo et al. 1989). In modern times, cantonal authorities in Switzerland have assumed an added responsibility to make periodic, careful monitoring visits to each alp on a rotating basis and to provide professional assessments and recommendations to local villages, thereby greatly 
enhancing the quality of knowledge and information about the sustainability of these resources.

Contrary to the expectation that communal property systems lacking the right to alienate ownership shares are markedly less efficient than property-rights systems involving full ownership, substantial evidence exists that many communal proprietorships effectively solve a wide diversity of local problems with relatively low transaction costs (Gaffney 1992; Hanna and Munasinghe 1995a, 1995b; Kaul 1996; Sandberg 1998). Obtaining valid and reliable measures of outputs and costs for a large number of property-rights systems covering similar activities in matched environmental settings is extremely difficult. In regard to irrigation, a series of careful studies of the performance of communal proprietorship systems as contrasted to government-owned and managed systems, clearly demonstrates the higher productivity of the communal systems controlling for relevant variables (Tang 1992; Benjamin et al. 1994; Lam 1998). Schlager's (1994) studies of inshore fisheries demonstrate that fishers who have clearly defined proprietorship are able to solve difficult assignment problems and assign the use of space and technology so as to increase both the efficiency and equity of their systems. James Wilson and colleagues' studies also demonstrate that communal proprietorship systems are more efficient than frequently thought (Wilson et al. 1994; Wilson, Yan, and Wilson 2007).

Performance of communal property-rights systems varies substantially, however, as do the performance of all property-rights systems. Some communal systems fail or limp along at the margin of effectiveness just as private firms fail or barely hang on to profitability over long periods of time. In addition to the environmental variables discussed above that are conducive in the first place to the use of communal proprietorship or ownership, the following variables related to the 
attributes of participants are conducive to their selection of norms, rules, and property rights that enhance the performance of communal property-rights systems (E. Ostrom 1993):

1. Accurate information about the condition of the resource and expected flow of benefits and costs is available at low cost to the participants (Blomquist 1992; Gilles and Jamtgaard 1981).

2. Participants share a common understanding about the potential benefits and risks associated with the continuance of the status quo as contrasted with changes in norms and rules that they could feasibly adopt (E. Ostrom 1990; Sethi and Somanathan 1996).

3. Participants share generalized norms of reciprocity and trust that can be used as initial social capital (Cordell and McKean 1992).

4. The group using the resource is relatively stable (Seabright 1993).

5. Participants plan to live and work in the same area for a long time (and in some cases, expect their offspring to live there as well) and, thus, do not heavily discount the future (Grima and Berkes 1989).

6. Participants use collective-choice rules that fall between the extremes of unanimity or control by a few (or even bare majority) and, thus, avoid high transaction or high deprivation costs (E. Ostrom 1990).

7. Participants can develop relatively accurate and low-cost monitoring and sanctioning arrangements (Berkes 1992).

Many of these variables are, in turn, affected by the type of larger regime in which users are embedded. If the larger regime recognizes the legitimacy of communal systems, and is facilitative of local self-organization by providing accurate information about natural resource systems, providing arenas in which participants 
can engage in discovery and conflict-resolution processes, and providing mechanisms to back up local monitoring and sanctioning efforts, the probability of participants adapting more effective rules over time is higher than in regimes that ignore resource problems or presume that all decisions about governance and management need to be made by central authorities.

Two additional variables — the size of a group and its homogeneity—have been noted as conducive to the initial organization of communal resources and to their successful performance over time (Agrawal 2000; Libecap 1989a, 1989b). As more research has been conducted, however, it is obvious that much more theoretical and empirical work is needed since both variables appear to have complex effects (Poteete and Ostrom 2004, 2008). Changing the size of a group, for example, always involves changing some of the other variables likely to affect the performance of a system. Increasing the size of a group is likely to be associated with at least the following changes: (1) an increase in the transaction costs of reaching agreements; (2) a reduction of the burden borne by each participant for meeting joint costs such as guarding a system, and maintenance; and (3) an increase in the amount of assets held by the group that could be used in times of emergency. Libecap (1995) found that it was particularly hard to get agreements to oil unitization with groups greater than four. Blomquist (1992), on the other hand, documents processes conducted in the shadow of an equity court that involved up to 750 participants in agreeing to common rules to allocate rights to withdraw water from groundwater basins in Southern California. The processes took a relatively long period of time, but they have now also survived with little administrative costs for half a century (Blomquist, Schlager, and Heikkila 2004). Agrawal and Goyal (2001) have shown that communal forestry institutions in India that are moderate in size are more likely to reduce overharvesting 
than are smaller groups because they tend to utilize a higher level of guarding than smaller groups.

Group heterogeneity is also multifaceted in its basic causal processes and effects. Groups can differ along many dimensions including their assets, their information, their valuation of final products, their production technologies, their time horizons, their exposure to risk (for example, headenders versus tailenders on irrigation systems), as well as their cultural belief systems (Varughese and Ostrom 2001). Libecap's (1989b) research on inshore fisheries has shown that when fishers have distinctively different production technologies and skills, all potential rules for sharing withdrawal rights have substantial distributional consequences and are the source of conflict that may not easily be overcome. Libecap and Wiggins’s (1984) studies of the prorationing of crude oil production reveal an interesting relationship between the levels and type of information available to participants and the likelihood of agreement at various stages in a bargaining process. In the early stages of negotiation, all oil producers share a relatively equal level of ignorance about the relative claims that each might be able to make under private-property arrangements. This is the most likely time for oil unitization agreements to be reached successfully. If agreement is not reached early, each participant gains asymmetric information about their own claims as more and more investment is made in private information. Agreements are unlikely at this stage. If producers then aggressively pump from a common oil pool, all tend to be harmed by the overproduction and are willing late in the process to recognize their joint interests. Libecap’s (1995) study of marketing agreements among orange growers also shows a strong negative impact of heterogeneity. The theoretical work of Mancur Olson (1965) on privileged groups, on the other hand, predicts that when some participants have substantial assets and whose 
interests are aligned with achieving an agreement, such groups are more likely to be organized. The empirical support for this proposition comes more from studies of global commons (Mitchell 1995; Oye and Maxwell 1995).

Heterogeneity in the knowledge and acceptance of local common-property regimes is likely to lead to their undoing. In frontier regions, new migrants increase the number of people sharing the return from a common-pool resource. Further, migrants are unlikely to recognize the legitimacy of extant, de facto, property-rights systems (see Alston, Libecap, and Schneider 1996). Thus, the common agreement necessary for the sustenance of any property-rights system may rapidly disappear if settlement patterns undergo a rapid change. Similarly, common-property systems related to inshore fisheries have also proved to be unstable when trawlers from other locations start to visit on a regular basis without recognizing the de facto property rights of local fishers.

\section{Attributes of common-pool resources conducive to the use of individual rights to withdrawal, management, exclusion, and alienation}

The advantage of individual ownership of strictly private goods-where the cost of exclusion is relatively low and one person's consumption is subtractive from what is available to others-is so well established that it does not merit attention here. Industrial and agricultural commodities clearly fit the definition of private goods. Individual rights to exclusion and to transferring control over these goods generate incentives that lead to higher levels of productivity than other forms of property arrangements.

It has frequently been assumed that land also is clearly always a private good and therefore best allocated using market mechanisms based on individual ownership rights. Agricultural land in densely settled regions is usually best allocated by a 
system of individual property rights. Gaining formal title to land, however, may or may not increase efficiency. Feder et al. (1988) conducted an important econometric study that showed that agricultural land in Thailand without a formal title was worth only one-half to two-thirds of land with a formal title. Further, increasing the security of private-property rights also led to an increased value of the crops produced (between one-tenth and one-fourth higher than those without secure title). More secure titling also provided better access to credit and led to greater investments in improved land productivity (see also Feder and Feeny 1991). Insecure property rights may lead potential users to arm and engage in violent conflict so as to gain control over land through force or by negotiation to avoid force. Several types of economic losses result from conflict over ownership (Umbeck 1981a, 1981b).

Title insurance is another mechanism used to reduce the risk of successful challenges to ownership of land. Registering brands is still another technique used to increase the security of ownership over resource units in the form of cattle that may range freely over a large area until there is a communal effort to undertake a roundup. Gaining formal titles is, however, costly. In societies that do not yet have high population densities and where customary rights are still commonly understood and accepted, formal titling may be an expensive method of increasing the security of a title that is not associated with a sufficiently higher return to be worth the economic investment (see Migot-Adholla et al. 1991). In addition, it should now be clear that the cost of fencing land by physical and/or institutional means is nontrivial and that there are types of land and land uses that may be more efficiently governed by groups of individuals rather than single individuals.

A commonly recommended solution to problems associated with the governance and management of mobile resource units, such as water and fish, is their 
‘privatization’ (Christy 1973; C. Clark 1980). Implementing operational and efficient individual withdrawal rights to mobile resources is far more difficult in practice than demonstrating the economic efficiency of hypothetical systems. Simply gaining valid and accurate measurements of 'sustainable yield' is a scientifically difficult task. In systems where resource units are stored naturally or by constructing facilities such as a dam, the availability of a defined quantity of the resource units can be ascertained with considerable accuracy, and buying, selling, and leasing rights to known quantities is relatively easy to effectuate in practice. Many mobile resource systems do not have natural or constructed storage facilities, and gaining accurate information about the stock and reproduction rates is very costly and involves considerable uncertainty (Allen and McGlade 1987; J. Wilson et al. 1991). Further, as Copes (1986) has clearly articulated, appropriators from such resources can engage in a wide diversity of evasive strategies that can destabilize the efforts of government agencies trying to manage these systems. Further, once such systems have allocated individual withdrawal rights, efforts to further regulate patterns of withdrawal may be very difficult and involve expensive buy-back schemes. Experience with these individual withdrawal-rights systems has varied greatly in practice (see McCay 1992; Wilson and Dickie 1995).

Exactly which attributes of both physical and social systems are most important to the success of individual withdrawal rights from common-pool resources is not as well established as the attributes of common-pool resource systems conducive to group proprietorship or ownership. On the physical side, gaining accurate measurements of the key variables (quantity, space, technology) that are to be involved in management efforts is essential. Resource systems that are naturally well-bounded facilitate measurement as well as ease of observing appropriation 
behavior. Storage also facilitates measurement. Where resource units move over vast terrain, the cost of measurement is higher than when they are contained (for example, it is easier to develop effective withdrawal-rights systems for lobsters than for whales).

Considerable recent research has also stressed the importance of involving participants in the design and implementation of such property-rights systems. When participants do not look upon such rules as legitimate, effective, and fair, the capacity to invent evasive strategies is substantial (Seabright 1993). The size of the group involved and the heterogeneity of participants also affect the costs of maintaining withdrawal-rights systems (Edwards 1994). And, the very process of allocating quantitative and transferable rights to resource units may undo some of the common understandings and norms that allowed communal ownership systems to operate at lower day-to-day administrative costs.

\section{Communal property regimes in the twenty-first century}

The focus of this entry has been primarily on natural resources. Many of the lessons learned from the operation of communal property regimes in these sectors, however, are quite relevant for a wide diversity of similar property regimes that are currently in wide use and likely to have a substantial presence in the next century. A very large number of housing developments—-both apartment houses and individual family dwellings - involve individual property to the housing unit itself combined with communal property to the grounds, recreational facilities, and other joint facilities. While individuals can buy and sell their individual housing units, at the time of purchase they assume a set of duties in respect to the closely related communal properties. Monthly assessments for the repair and maintenance of these common 
facilities are not unlike the assessments made by a community of irrigators on themselves for the maintenance of their own system. Further, purchase and sales frequently require the permission of other members of the group. Similarly, many sports clubs allocate use quotas to members and assess members' regular fees for the maintenance of the commonly owned facilities.

The modern corporation is frequently thought of as the epitome of private property. While buying and selling shares of corporate stock is a clear example of the rights of alienation at work, relationships within a firm are far from being 'individual' ownership rights. Since the income that will be shared among stockholders, management, and employees is itself a common pool to be shared, all of the incentives leading to free riding (shirking) and overuse (padding the budget) are found within the structure of a modern corporation (Ghoshal and Moran 1996; Putterman 1995; Seabright 1993). Thus, where many individuals will work, live, and play in the next century will be governed and managed by mixed systems of communal and individual property rights.

\section{Notes on the bibliography}

The updated and revised bibliography ${ }^{1}$ adds well over 200 additional citations to the earlier version. We have selected articles and books that continue the tradition of common property scholarship as well as those that reflect new trends in this area of study. Noteworthy stronger foci are sustainability, the global commons, property regimes in transition, and the intersection of intellectual property rights and environmental goods.

The crucial questions surrounding common-property management have continued to be ones of equity, efficiency and sustainability. Since the turn of this past 
century, however, the issue of sustainability has increased in its importance and visibility in the commons literature (see, for instance, Agrawal 2001; Anderies et al. 2007; Bressers and Kuks 2004; Costanza et al. 2001; Kamara, Kirk, and Swallow 2004; Marshall, Fritsch, and Dulhunty 2005; McMahon 2006; Meinzen-Dick and Di Gregorio 2004; Ørebech et al. 2005; Oses-Erasoa and Viladrich-Grau 2007; Pasqual and Souto 2003; Smajgl and Larson 2007; Veeman and Politylo 2003). Ecological economist Robert Costanza (2000) writes:

The most critical task facing humanity today is the creation of a shared vision of a sustainable and desirable society, one that can provide permanent prosperity within the biophysical constraints of the real world in a way that is fair and equitable to all of humanity, to other species, and to future generations.

Some authors argue that developing new common-property regimes may be helpful in achieving sustainability (Buck 2002; Brunckhorst 2003; Buxton 2004; Marshall, Fritsch, and Dulhunty 2005; Williamson, Brunckhorst, and Kelly 2003).

New research demonstrates the urgent need for effective approaches to commons problems that are global in scale (E. Ostrom et al. 1999). Particular areas of focus on the global commons in this bibliography are biodiversity (Choudry 2005; Coban 2004; Goeschl and Igliori 2006; Tisdell 2004; Trommetter 2005) and water resources (Becker and Easter 1999; Dilworth 2007; Dinar 2000; Fisher 2004; Smets 2004).

Common-property regimes in transition is a another noteworthy recurrent theme (see Banner 2002; Dekker 2003; Mwangi 2006, 2007a, 2007b; Majumdar 
2007; J. Marshall 2001; John McCarthy 2000; Moyo 2005; Muñoz Piña, de Janvry, and Sadoulet 2003; Okello 2005; Rao et al. 2003; D. Thompson 2006). Mwangi (2007b), for instance, illustrates the complexity of regime change in her research on the transition from collective to individualized rights in Kenya's Maasailand and the complications of politics and procedural problems. The ambiguity of certain property regimes leads a number of researchers to examine "who owns” various resources (Barnes 2001 [sky]; F. Brown 2003 [native culture]; Gepts 2004 [biodiversity]; Ho 2001 [land]; Macinko and Bromley 2002 [fisheries]). Privatization is another kind of regime transition of great concern regardless of which kind of resource is involved (for representative works see Hannesson 2006; Hedlund 2001; Lesorogol 2003; Mansfield 2004; National Research Council 2001).

Another growing area of study is the intersection of traditional property rights and intellectual property rights. Drahos and Mayne (2003) write that patents, as types of intellectual property rights, can reduce access to knowledge in such life-sustaining areas as genetics, health, and agriculture - a problem even worse in developing countries. Aoki calls one of these intersections 'seed wars'-battles 'over the ownership of intellectual property rights of germplasm—arguments over weeds, seeds and deeds’ (Aoki 2003; see also Borowiak 2004; Dutfield 2000; C. Thompson 2004). A number of works focus on rights to plant genetic resources and threats to indigenous knowledge and systems of agriculture (Barnett 2000; Dickenson 2004; Eyzaguirre et al. 2004; Kennedy 2006; Rifkin 2002; Spier 2001).

\section{Acknowledgments}

Support from the National Science Foundation (Grant Nos. SBR-9319835 and SBR95 21918), the Ford Foundation, and the Andrew W. Mellon Foundation is gratefully 
acknowledged. Comments on an initial draft of this entry by Arun Agrawal, David Feeny, Vincent Ostrom, Peter Ørebech, and Jimmy Walker are gratefully acknowledged. The comments of two anonymous reviewers were of considerable value. The editing skills of Patty Lezotte have been, as usual, of immense assistance-particularly in a paper involving such an extensive bibliography as Charlotte Hess and I have prepared for this entry.

\section{Notes}

${ }^{1}$ The commons database in the library of the Workshop in Political Theory and Policy Analysis contains 50,500 records of literature on the commons, common-pool resources, and common property. Of those, 779 have "common property" in the title. 
Bibliography on Private and Common Property Rights (2007)

(by Charlotte Hess and Elinor Ostrom)

Acheson, James M. (1988), The Lobster Gangs of Maine, Hanover, NH: University Press of New England.

Acheson, James M. (2000), 'Clearcutting Maine: Implications for the theory of common property resources', Human Ecology, 28, 145-169.

Acheson, James M. (2003), Capturing the Commons: Devising Institutions to Manage the Maine Lobster Industry, Lebanon, NH: University Press of New England.

Adger, W. Neil and Cecilia Luttrell (2000), 'Property rights and the utilisation of wetlands', Ecological Economics, 35, 75-89.

Adhikari, Bhim (2005), 'Poverty, property rights and collective action: Understanding the distributive aspects of common property resource management', Environment and Development Economics, 10, 7-31.

Agrawal, Arun (1999), Greener Pastures: Politics, Markets, and Community among a Migrant Pastoral People, Durham, NC: Duke University Press.

Agrawal, Arun (2000), 'Small is beautiful, but is larger better? Forest-management institutions in the Kumaon Himalaya, India’, in Clark Gibson, Margaret McKean, and Elinor Ostrom (eds), People and Forests: Communities, Institutions, and Governance, Cambridge, MA: MIT Press, pp. 57-86.

Agrawal, Arun (2001), 'Common property institutions and sustainable governance of resources', World Development, 29, 1649-1672.

Agrawal, Arun (2005), Environmentality: Technologies of Government and the Making of Subjects, Durham, NC: Duke University Press. 
Agrawal, Arun and Elinor Ostrom (2001), 'Collective action, property rights, and decentralization in resource use in India and Nepal', Politics and Society, 29, 485-514.

Agrawal, Arun and Sanjeev Goyal (2001), ‘Group size and collective action: Thirdparty monitoring in common-pool resources', Comparative Political Studies, 34 (1), 63-93.

Aguilera-Klink, Federico (1994), 'Some notes on the misuse of classic writings in economics on the subject of common property', Ecological Economics, 9 (3), $221-228$.

Alchian, Armen A. (1965), 'Some economics of property rights', Il Politico, 30, 816829.

Alchian, Armen A. and Harold Demsetz (1973), 'The property rights paradigm’, Journal of Economic History, 33, 16-27.

Alcock, F. (2002), 'Bargaining, uncertainty, and property rights in fisheries', World Politics, 54, 437-461.

Alcorn, J. B. and A. G. Royo (eds) (2000), Indigenous Social Movements and Ecological Resilience: Lessons from the Dayak of Indonesia, Washington, DC: World Wildlife Fund.

Allen, P. M. and J. M. McGlade (1987), 'Modelling complex human systems: A fisheries example’, European Journal of Operational Research, 30, 147-167.

Alston, Lee J., Thráinn Eggertsson, and Douglass C. North (eds) (1996), Empirical Studies in Institutional Change, New York: Cambridge University Press.

Alston, Lee J., Gary Libecap, and Robert Schneider (1996), 'The determinants and impact of property rights: Land titles on the Brazilian frontier', Journal of Law, Economics and Organization, 12, 25-61. 
Altman, Jon C. (2004), 'Economic development and indigenous Australia: Contestations over property, institutions and ideology', Australian Journal of Agricultural and Resource Economics 48, 513-534.

Andelson, Robert V. (ed.) (1991), Commons without Tragedy: The Social Ecology of Land Tenure and Democracy, London: Centre for Incentive Taxation.

Anderies, John M., Armando A. Rodriguez, Marco A. Janssen, and Oguzhan Cifdaloz (2007), 'Panaceas, uncertainty, and the robust control framework in sustainability science', Proceedings of the National Academy of Sciences, 104 (39), 15194-15199.

Anderson, C. L. and E. Swimmer (1997), 'Some empirical evidence on property rights of first peoples’, Journal of Economic Behavior and Organization, 33 (1), 1-22.

Anderson, Terry L. (2004), 'Donning Coase-colored glasses: A property rights view of natural resource economics', Australian Journal of Agricultural and Resource Economics, 48, 445-462.

Anderson, Terry L. and Peter J. Hill (eds) (2001), The Technology of Property Rights, Lanham, MD: Rowman \& Littlefield.

Anderson, Terry L. and Peter J. Hill (2004), The Not So Wild, Wild West: Property Rights on the Frontier, Stanford, CA: Stanford University Press.

Anderson, Terry L. and Dean Lueck (1992), 'Land tenure and agricultural productivity on Indian reservations', Journal of Law and Economics, 35, 427454.

Anderson, Terry L. and Fred S. McChesney (eds) (2003), Property Rights: Cooperation, Conflict, and Law, Princeton, NJ: Princeton University Press. 
Aoki, Keith (1998), 'Neocolonialism, anticommons property, and biopiracy in the (not-so-brave) new world order of international intellectual property protection', Indiana Journal of Global Legal Studies, 6 (1), 11-38.

Aoki, Keith (2003), 'Weeds, seeds \& deeds: Recent skirmishes in the seed wars', Cardozo Journal of International and Comparative Law, 11, 247-331.

Apostle, Richard, Bonnie McCay, and Knut H. Mikalsen (2002), Enclosing the Commons: Individual Transferable Quotas in the Nova Scotia Fishery, St. John’s, Newfoundland: ISER Books.

Arnason, Ragnar (2005), 'Property rights in fisheries: Iceland’s experience with ITQs', Reviews in Fish Biology and Fisheries, 15, 243-264.

Arnold, Craig Anthony (2002), 'The reconstitution of property: Property as a web of interests', Harvard Environmental Law Review, 26, 281-364.

Arnold, Gwen (2003), 'Collective action for common pool resource management in Michigan inland lake communities’, Michigan Journal of Political Science, 2, 1-97.

Arnold, J.E.M. (1993), 'Management of forest resources as common property', Commonwealth Forestry Review, 72, 157-161.

Arnold, J.E.M. and J. Gabriel Campbell (1986), ‘Collective management of hill forests in Nepal: The community forestry development project', in National Research Council, Proceedings of the Conference on Common Property Resource Management, Washington, DC: National Academy Press, pp. 425454.

Arnold, J.E.M. and W. C. Stewart (1989), Common Property Resource Management in India, Oxford: Oxford Forestry Institute, University of Oxford, Department of Plant Sciences, Tropical Forestry Papers no. 24. 
Ascher, William (1995), Communities and Sustainable Forestry in Developing Countries, San Francisco, CA: ICS Press.

Ashenafi, Zelealem, and N. Leader-Williams (2005), 'Indigenous common property resource management in the central highlands of Ethiopia’, Human Ecology, 33, 539-563.

Atran, Scott (1993), 'Itza Maya tropical agro-forestry’, Current Anthropology, 34, $633-700$.

Axelby, Richard (2007), ““It takes two hands to clap”: How Gaddi shepherds in the Indian Himalayas negotiate access to grazing', Journal of Agrarian Change, 7, $35-75$.

Baack, Bennett (1982), 'Testing the impact of exclusive property rights: The case of enclosing commons fields', in Roger Ransom, Richard Sutch, and Gary Walton (eds), Explorations in the New Economic History: Essays in Honor of Douglass C. North, New York: Academic Press.

Baden, John (1977), 'A primer for the management of common pool resources', in Garrett Hardin and John Baden (eds), Managing the Commons, San Francisco, CA: W. H. Freeman.

Baird, John S. (1982), 'Conservation of the commons: Effects of group cohesiveness and prior sharing', Journal of Community Psychology, 10, 210-215.

Baker, Kenneth and Michael McKee (2000), 'Increasingly contested property rights and trading in environmental amenities', Land Economics, 76, 333-344.

Baker, Matthew, Thomas Miceli, C. F. Sirmans, and Geoffrey K. Turnbull (2001), 'Property rights by squatting: Land ownership risk and adverse possession statutes', Land Economics, 77, 360-370. 
Baland, Jean-Marie and Patrick Francois (2005), 'Commons as insurance and the welfare impact of privatization', Journal of Public Economics, 89, 211-231.

Baland, Jean-Marie and Jean-Philippe Platteau (1996), Halting Degradation of Natural Resources: Is There A Role for Rural Communities?, New York: Oxford University Press and FAO.

Baland, Jean-Marie and Jean-Philippe Platteau (1998), 'Division of the commons: A partial assessment of the new institutional economics of land rights', American Journal of Agricultural Economics, 80 (3), 644-657.

Baland, Jean-Marie and Jean-Philippe Platteau (2003), 'Economics of common property management regimes', Handbook in Economics, 20, 127-184.

Banks, Tony (2001), 'Property rights and the environment in pastoral China: Evidence from the field', Development and Change, 32, 717-740.

Banks, Tony (2003), 'Property rights reform in rangeland China: Dilemmas on the road to the household ranch', World Development, 31, 2129-2142.

Banner, Stuart (2002), 'Transitions between property regimes', Journal of Legal Studies, 31, S359-S371.

Barbanell, Edward M. (2001), Common-Property Arrangements and Scarce Resources: Water in the American West, Westport, CT: Praeger.

Bardhan, Pranab K. (ed.) (1989), The Economic Theory of Agrarian Institutions, Oxford: Clarendon Press.

Bardhan, Prahab K. (2005a), 'Institutions matter, but which ones?’, Economics of Transition, 13, 499-532.

Bardhan, Pranab K. (ed.) (2005b), Scarcity, Conflicts, and Cooperation: Essays in the Political and Institutional Economics of Development, Cambridge, MA: MIT Press. 
Barnes, Peter (2001), Who Owns the Sky? Our Common Assets and the Future of Capitalism, Washington, DC: Island Press.

Barnes, Peter (2006), Capitalism 3.0: A Guide to Reclaiming the Commons, San Francisco, CA: Berrett-Koehler.

Barnett, Jonathan M. (2000), 'Cultivating the genetic commons: Imperfect patent protection and the network model of innovation', San Diego Law Review, 37 (4), 987-1067.

Barzel, Yoram (1991), Economic Analysis of Property Rights, New York: Cambridge University Press.

Barzel, Yoram (2002), A Theory of the State: Economic Rights, Legal Rights, and the Scope of the State, New York: Cambridge University Press.

Beck, Tony and Cathy Nesmith (2001), ‘Building on poor people’s capacities: The case of common property resources in India and West Africa’, World Development, 29, 119-133.

Becker, Marc (2007), 'Indigenous struggles for land rights in twentieth-century Ecuador', Agricultural History, 81, 159-181.

Becker, Nir and K. William Easter (1999), 'Conflict and cooperation in managing international water resources such as the Great Lakes’, Land Economics, 75 (2), 233-245.

Behnke, Roy H., Jr. (1985), ‘Open-range management and property rights in pastoral Africa: A case of spontaneous range enclosure in South Darfur, Sudan’, London: Overseas Development Institute.

Béné, Christophe, A. Neiland, T. Jolley, B. Ladu, S. Ovie, O. Sule, M. Baba, et al. (2003), 'Natural resource institutions and property rights in inland African 
fisheries: The case of the Lake Chad basin region', International Journal of Social Economics, 30, 275-301.

Bengwayan, Michael A. (2003), Intellectual and Cultural Property Rights of Indigenous and Tribal Peoples in Asia, London: Minority Rights Group. Benjamin, Paul, Wai Fung Lam, Elinor Ostrom, and Ganesh Shivakoti (1994), Institutions, Incentives, and Irrigation in Nepal, Decentralization: Finance \& Management Project Report, Burlington, VT: Associates in Rural Development.

Benjaminsen, Tor Arve, Ben Cousins, and Lisa Thompson (eds) (2002), Contested Resources: Challenges to the Governance of Natural Resources in Southern Africa, Cape Town: Programme for Land and Agrarian Studies (PLAAS).

Benjaminsen, Tor A. and Christian Lund (eds) (2001), Politics, Property and Production in the West African Sahel: Understanding Natural Resources Management, Uppsala and London: Nordic Africa Institute and Global. Benjaminsen, Tor A. and Christian Lund (2002), 'Formalisation and informalisation of land and water rights in Africa: An introduction', European Journal of Development Research, 14, 1-10.

Berck, P. (1979), ‘Open access and extinction’, Econometrica, 47, 877-882.

Berge, Erling (ed.) (1993), Common Property Regimes: Law and Management of Non-Private Resources: Proceedings of the Conference; Vols. I-II, Ås, Norway: Agricultural University of Norway.

Berge, Erling and Nils Stenseth (eds) (1995), Law and the Management of Renewable Resources, Trondheim, Norway: University of Trondheim, Department of Sociology and Political Science. 
Berkes, Fikret (ed.) (1989), Common Property Resources; Ecology and CommunityBased Sustainable Development, London: Belhaven.

Berkes, Fikret (1992), ‘Success and failure in marine coastal fisheries of Turkey’, in Daniel W. Bromley, et al. (eds), Making the Commons Work: Theory, Practice, and Policy, San Francisco, CA: ICS Press, pp. 161-182.

Berkes, Fikret (2004), ‘Rethinking community-based conservation', Conservation Biology, 18, 621-630.

Berkes, Fikret (2007), 'Community-based conservation in a globalized world', Proceedings of the National Academy of Sciences, 104 (39), 15188-15193.

Berry, Sara S. (2000), Chiefs Know Their Boundaries: Essays on Property, Power, and the Past in Asante, 1896-1996, Westport, CT: Heinemann.

Blackstone, William (1766), Commentaries on the Laws of England, Book II, Chicago: University of Chicago Press.

Blaikie, Piers M. and Harold C. Brookfield (eds) (1987), Land Degradation and Society, New York: Methuen.

Blomley, N. (2007), 'Making private property: Enclosure, common right and the work of hedges', Rural History 18, 1-22.

Blomquist, William (1992), Dividing the Waters: Governing Groundwater in Southern California, San Francisco, CA: ICS Press.

Blomquist, William and Elinor Ostrom (1985), 'Institutional capacity and the resolution of a commons dilemma', Policy Studies Review, 5, 383-393.

Blomquist, William, Edella Schlager, and Tanya Heikkila (2004), Common Waters, Diverging Streams: Linking Institutions and Water Management in Arizona, California, and Colorado, Washington, DC: Resources for the Future. 
Bolle, F. (1986), 'On the oligopolistic extraction of non-renewable common-pool resources', Economics, 53, 519-527.

Borowiak, Craig (2004), 'Farmers’ rights: Intellectual property regimes and the struggle over seeds', Politics and Society, 32, 511-543.

Brandt, Sylvia (2007), 'Evaluating tradable property rights for natural resources: The role of strategic entry and exit', Journal of Economic Behavior and Organization, 63, 158-176.

Brandt, Sylvia and D. McEvoy (2006), 'Distributional effects of property rights: Transitions in the Atlantic herring fishery’, Marine Policy, 30, 659-670.

Brara, Rita (2006), Shifting Landscapes: The Making and Remaking of Village Commons in India, New York: Oxford University Press.

Breemer, J. D. (2004), ‘What property rights: The California coastal commission’s history of abusing land rights and some thoughts on the underlying causes', UCLA Journal of Environmental Law and Policy, 22, 247-300.

Bressers, Hans and Stefan Kuks (eds) (2004), Integrated Governance and Water Basin Management: Conditions for Regime Change and Sustainability, Boston, MA: Kluwer Academic.

Brock, William A. and Stephen R. Carpenter (2007), 'Panaceas and diversification of environmental policy', Proceedings of the National Academy of Sciences, 104 (39), 15206-15211.

Bromley, Daniel W. (1991), Environment and Economy: Property Rights and Public Policy, Cambridge, MA: Basil Blackwell.

Bromley, Daniel W. (1992), 'The commons, common property, and environmental policy', 2 Environmental and Resource Economics, 1-17. 
Bromley, Daniel W. (2000), 'Property regimes and pricing regimes in water resource management', in A. Dinar (ed.), The Political Economy of Water Pricing Reforms, New York: Oxford, pp. 29-48.

Bromley, Daniel W., David Feeny, Margaret McKean, Pauline Peters, Jere Gilles, Ronald Oakerson, C. Ford Runge, and James Thomson (eds) (1992), Making the Commons Work: Theory, Practice, and Policy, San Francisco, CA: ICS Press.

Brooks, R., S. Davidson, and R. Faff (2003), 'Sudden changes in property rights: The case of Australian native title,' Journal of Economic Behavior and Organization, 52, 427-442.

Brown, G., B. Berger, and M. Ikiara (2005), 'Different property rights regimes in the Lake Victoria multiple species fishery', Environment and Development Economics, 10, 53-65.

Brown, K. M. (2006a), 'New challenges for old commons: The role of historical common land in contemporary rural spaces’, Scottish Geographical Journal, 122, 109-129.

Brown, K. M. (2006b), 'The role of moral values in contemporary common property enactment', Norsk Geografisk Tidsskrift, 60, 89-99.

Brown, Michael F. (2003), Who Owns Native Culture?, Cambridge, MA: Harvard University Press.

Brox, Ottar (1990), 'The common property theory: Epistemological status and analytical utility’, Human Organization, 49, 227-235.

Bruce, John W. (1995), Legal Bases for the Management of Land-Based Natural Resources as Common Property, Forests, Trees and People Programme, Rome, Italy: Food and Agriculture Organization of the United Nations. 
Bruce, John W., Louise Fortmann, and Calvin Nhira (1993), 'Tenures in transition, tenures in conflict: Examples from the Zimbabwe social forest', Rural Sociology, 58, 626-642.

Bruce, John W. and Shem E. Migot-Adholla (eds) (1994), Searching for Land Tenure Security in Africa, Dubuque, IA: Kendall/Hunt.

Brunckhorst, David J. (2003), 'Factors in the success of common property resource institutions', Ecological Management and Restoration, 4, 72-73.

Bruns, Bryan Randolph and Ruth Meinzen-Dick (eds) (2000), Negotiating Water Rights, New Delhi, India: Vistaar for the International Food Policy Research Institute.

Bruns, Bryan Randolph, Claudia Ringler, and Ruth Meinzen-Dick (eds) (2005), Water Rights Reform: Lesson for Institutional Design, Washington, DC: International Food Policy Research Institute.

Buchanan, James M. and Gordon Tullock (1965), The Calculus of Consent: Logical Foundations of Constitutional Democracy, Ann Arbor: University of Michigan Press.

Buck, Stuart (2002), 'Replacing spectrum auctions with a spectrum commons’, Stanford Technology Law Journal 2, http://stlr.stanford.edu/STLR/Articles/02_STLR_2

Burger, Joanna, Elinor Ostrom, Richard Norgaard, David Policansky, and Bernard Goldstein (eds) (2000), Protecting the Commons: A Framework for Resource Management in the Americas, Covelo, CA: Island Press.

Burling, J. S. (2002), 'Private property rights and the environment after Palazzolo', Boston College Environmental Affairs Law Review, 30, 1-64. 
Burling, J. S. (2006), 'First we need real property rights', Environmental Forum, 23, 23-27.

Burton, P. S. (2004), 'Hugging trees: Claiming de facto property rights by blockading resource use', Environmental and Resource Economics, 27, 135-163.

Butler, L. L. (2000), ‘The pathology of property norms: Living within nature’s boundaries', Southern California Law Review, 73, 927-1015.

Buxton, Carol R. (2004), 'Property in outer space: The common heritage of mankind principle vs. the “first in time, first in right” rule of property law', Journal of Air Law and Commerce, 69, 689-707.

Cahir, John (2004), ‘The withering away of property rights', Oxford Journal of Legal Studies, 24, 619-641.

Calabresi, Guido and A. Douglas Melamed (1972), 'Property rules, liability rules, and inalienability: One view of the cathedral', Harvard Law Review, 85, 10891128.

Caleys, Eric R. (2006), ‘Natural property rights and privatization: A comment on Professor Rose', Saint Louis Law Journal, 50, 721-734.

Campbell, Bruce, Alois Mandondo, Nontokozo Nemarundwe, Bevlyne Sithole, Wil De JonG, Marty Luckert, and Frank Matose (2001), 'Challenges to proponents of common property resource systems: Despairing voices from the social forests of Zimbabwe', World Development, 29, 589-600.

Caputo, M. R. and D. Lueck (2003), 'Natural resource exploitation under common property rights', Natural Resource Modeling, 16, 39-68.

Carpenter, Kristin A. (2005), ‘A property rights approach to sacred sites cases: Asserting a place for Indians as nonowners', UCLA Law Review, 52, 10611148. 
Casari, Mario (2007), 'Emergence of endogenous legal institutions: Property rights and community governance in the Italian Alps', Journal of Economic History, 67, 191-226.

Casimir, Michael J. (1990), 'The determinants of rights to pasture: Territorial organization and ecological constraints', in M. J. Casimir and A. Rao (eds), Mobility and Territoriality, New York: Berg.

Cernea, Michael M. (ed.) (1991), Putting People First: Sociological Variables in Rural Development, 2nd ed., New York: Oxford University Press.

Chakraborty, Rabindra Nath (2001), 'Stability and outcomes of common property institutions in Forestry: Evidence from the Terai region of Nepal', Ecological Economics, 36, 341-353.

Chan, Nelson (2001), 'How new land use rights are changing communal property and China’s cities', Australian Property Journal, 36, 629-635.

Chaudhry, Shivani and Owen J. Lynch (eds) (2002), Amplifying Local Voices, Striving for Environmental Justice: Proceedings of the African Public Interest Law and Community-Based Property Rights Workshop, Usa River, Arusha, Tanzania, August 1-4, 2000, Washington, DC: Center for International Environmental Law.

Chavez, Carlos and Hugo Salgado (2005), 'Individual transferable quota markets under illegal fishing', Environmental and Resource Economics, 31, 303-324.

Cheever, F. (2002), 'Property rights and the maintenance of wildlife habitat: The case for conservation land transactions', Idaho Law Review, 38, 431-452.

Cheikbossian, G. (2003), 'Property rights, rent-seeking and aggregate outcomes in transition economies', Economic Systems, 27, 271-288. 
Chen, C. H. (2002), 'Property rights and rural development in China’s transitional economy’, Economics of Planning, 35, 349-363.

Chen, F. (2002), 'An analysis of water transaction by the way of economics of property rights', Chinese Rural Economy, 10, 25-29.

Chen, J. (2004), 'Webs of life: Biodiversity conservation as a species of information policy’, Iowa Law Review, 89, 495-608.

Cheung, S. N. S. (1970), 'The structure of a contract and the theory of a nonexclusive resource', Journal of Law and Economics, 13, 49-70.

Chimhowu, Admos and Phil Woodhouse (2006), 'Customary vs. private property rights? Dynamics and trajectories of vernacular land markets in sub-Saharan Africa', Journal of Agrarian Change, 6, 346-371.

Chopra, Kanchan and S. C. Gulati (2001), Migration, Common Property Resources and Environmental Degradation: Interlinkages in India's Arid and Semi-Arid Regions, Thousand Oaks, CA: Sage.

Choudry, Aziz (2005), 'Privatizing nature: Plundering biodiversity’, in Ernst Ulrich von Weizsäcker, Oran R. Young, and Matthias Finger (eds), Limits to Privatization: How to Avoid too Much of a Good Thing, Sterling, VA: Earthscan, pp. 58-61.

Christy, Francis T. (1973), Fisherman Quotas: A Tentative Suggestion for Domestic Management, Kingston: University of Rhode Island, Law of the Sea Institute. Ciriacy-Wantrup, Siegfried V. (1963), Resource Conservation: Economics and Policies, rev. ed., Berkeley: University of California, Division of Agricultural Sciences. 
Ciriacy-Wantrup, Siegfried V. and Richard C. Bishop (1975), ““Common property” as a concept in natural resource policy’, Natural Resources Journal, 15, 713727.

Clark, Colin W. (1976), Mathematical Bioeconomics: The Optimal Management of Renewable Resources, New York: Wiley.

Clark, Colin W. (1980), 'Restricted access to common-property fishery resources: A game theoretic analysis’, in Pan-Tai Liu (ed.), Dynamic Optimization and Mathematical Economics, New York: Plenum, pp. 117-132.

Clark, J. Stephen and Gerald A. Carlson (1991), ‘Testing for common versus private property: The case of pesticide resistance', Discussion, 21, 92-96.

Cleaver, Frances (2000), 'Moral ecological rationality, institutions and the management of common property resources’, Development and Change, 31, $361-383$.

Co, Catherine Y., John A. List, and Larry D. Qui (2004), 'Intellectual property rights, environmental regulations, and investment', Land Economics, 80, 153-173.

Coase, Ronald H. (1960), 'The problem of social cost', Journal of Law and Economics, 3, 1-44.

Coban, Aykut (2004), 'Caught between state-sovereign rights and property rights: Regulating biodiversity', Review of International Political Economy, 11, 736762.

Colchester, M. (2003), 'Indigenous peoples and protected areas: Rights, principles and practice', Nomadic Peoples, 7, 33-51.

Cole, Daniel H. (2002), Pollution and Property: Comparing Ownership Institutions for Environmental Protection, New York: Cambridge University Press. 
Cole, Daniel H. and Peter Z. Grossman (2002), 'The meaning of property rights: Law versus economics?', Land Economics, 78, 317-330.

Commons, John R. (1968), Legal Foundations of Capitalism, Madison: University of Wisconsin Press.

Congost, Rosa (2003), 'Property Rights and Historical Analysis: What Rights? What History?', Past and Present, 181, 73-106.

Copes, Parzival (1984), 'The market as an open access commons: A neglected aspect of excess capacity’, Economist, 132, 49-60.

Copes, Parzival (1986), 'A critical review of the individual quota as a device in fisheries management', Land Economics, 62, 278-291.

Cordell, John C. and Margaret A. McKean (1992), 'Sea tenure in Bahia, Brazil’, in Daniel W. Bromley, et al. (eds), Making the Commons Work: Theory, Practice, and Policy, San Francisco, CA: ICS Press, pp. 183-205.

Cornes, Richard, Charles F. Mason, and Todd Sandler (1986), 'The commons and the optimal number of firms', Quarterly Journal of Economics, 101, 641-646.

Cornes, Richard and Todd Sandler (1986), ‘On commons and tragedies’, American Economic Review, 83, 787-792.

Costanza, Robert (2000), 'Visions of alternative (unpredictable) futures and their use in policy analysis', Ecology and Society, 4 (1), http://www.ecologyandsociety.org/vol4/iss1/art5/

Costanza, Robert, Bobbi S. Low, Elinor Ostrom, and James Wilson (eds) (2001), Institutions, Ecosystems, and Sustainability, New York: Lewis Publishers.

Coulibaly, Cheibane (ed.) (2006), Questions de Gouvernance, Bamako, Mali: Editions Le Cauri d’Or. (Les Cahiers de Mande Bukari, Numéro 04). 
Coward, E. Walter, Jr. (ed.) (1980), Irrigation and Agricultural Development in Asia: Perspectives from the Social Sciences, Ithaca, NY: Cornell University Press.

Cox, Susan (1985), 'No tragedy on the commons', Environmental Ethics, 7, 49-61.

Coyle, Sean and Karen Morrow (2004), The Philosophical Foundations of Environmental Law: Property, Rights and Nature, Portland, OR: Hart Publishing.

Crawford, Sue E. S. and Elinor Ostrom (2005), ‘A grammar of institutions’, in Elinor Ostrom (ed.), Understanding Institutional Diversity, Princeton, NJ: Princeton University Press, pp. 137-174. Originally published in American Political Science Review 89(3) (September 1995), 582-600.

Cremers, Leontien, Marjolein Ooijevaar, and Rutgerd Boelens (2005), 'Institutional reform in the Andean irrigation sector: Enabling policies for strengthening local rights and water wanagement', Natural Resources Forum, 29, 37-50.

Croson, Rachel and Jason Scott Johnston (2000), ‘Experimental results on bargaining under alternative property rights regimes', Journal of Law, Economics, and Organization, 16, 50-73.

Cruz, S. D. and A. V. Raikar (2006), 'Democratic management of common property in Goa: From “Gaonkarias” and “Communidades” to Gram Sabhas’, Economic and Political Weekly, 41, 439-445.

Cruz, Wilfrido D. (1986), 'Overfishing and conflict in a traditional fishery: San Miguel Bay, Philippines’, in National Research Council, Proceedings of the Conference on Common Property Resource Management, Washington, DC: National Academy Press, pp. 115-135.

Cullet, P. (2001), 'Property-rights regimes over biological resources’, Environment and Planning C, 19, 651-664. 
Cummings, Sarah, Minke Valk, and Henk van Dam (eds) (2001), Gender Perspectives on Inheritance and Property: Rights and Reality: A Global Source Book, Oxford, UK: Oxfam.

Curran, Sara R. and Tundi Agardy (2002), 'Common property systems, migration, and coastal ecosystems', Ambio, 31, 303-305.

Curry, Janel M. and Steven McGuire (2002), Community on Land: Community, Ecology, and the Public Interest, Lanham, MD: Rowman \& Littlefield.

Curtis, Donald (1991), Beyond Government: Organizations for Common Benefit, London: Macmillan.

Cutting, R. H. (2001), ““One man’s ceilin’ is another man’s floor”: Property rights as the double-edged sword', Environmental Law, 31, 819-900.

Dabla-Norris, Era and Scott Freeman (2004), 'Enforcement of property rights and underdevelopment', Review of Development Economics, 8, 391-405.

Dadibhavi, R. V. (2000), 'Management of common property resources: A review and some policy issues', Journal of Rural Development, 19, 199-217.

Dales, John H. (1968), Pollution, Property, and Prices: An Essay in Policy-Making and Economics, Toronto: University of Toronto Press.

Dalton, T. R., R. M. Coats, and B. R. Asrabadi (2005), 'Renewable resources, property rights regimes and endogenous growth', Ecological Economics, 52, 31-41.

Damodaran, A. (2001), ‘WTO agriculture agreement, common property resources and income diversification strategy', Economic and Political Weekly, 36, 36333642.

Daniels, Brigham A. (2007), 'Emerging commons and tragic institutions’, Environmental Law, 37, 515-571. 
Dasgupta, Partha (1982), The Control of Resources, Cambridge, MA: Harvard University Press.

Dasgupta, Partha (2005), 'Common property resources: Economic analytics’, Economic and Political Weekly, 40, 1610-1622.

Dasgupta, Partha and Geoffrey M. Heal (1979), Economic Theory and Exhaustible Resources, Garden City, NJ: J. Nisbet.

De Alessi, Louis (1980), 'The economics of property rights: A review of the evidence', Research in Law and Economics, 2, 1-47.

De Alessi, Louis (1982), 'On the nature and consequences of private and public enterprises', Minnesota Law Review, 67, 191-209.

Deere, Carmen Diana and Magdalena León (2001), Empowering Women: Land and Property Rights in Latin America, Pittsburgh, PA: University of Pittsburgh Press.

Dekker, Henri A. L. (2003), Property Regimes in Transition: Land Reform, Food Security and Economic Development: A Case Study in the Kyrgyz Republic, Burlington, VT: Ashgate.

de Moor, Martina and P. Warde (eds) (2002), The Management of Common Land in North West Europe, c. 1500-1850, Turnhout, Belgium: Brepols.

Demsetz, Harold (1964), 'The exchange and enforcement of property rights’, Journal of Law and Economics, 7, 11-26.

Demsetz, Harold (1967), 'Toward a theory of property rights’, American Economic Review, 62, 347-359.

de Soto, Hernando (2000), The Mystery of Capital: Why Capitalism Triumphs in the West and Fails Everywhere Else, New York: Perseus. 
Devany, A. S., R. Eckert, C. Meyers, D. O’Hara, and R. Scott (1969), ‘A property system for market allocation of electro-magnetic spectrum: A legal-economicengineering study', Stanford Law Review, 30, 1499-1561.

deWaal, Clarissa (2004), 'Post-socialist property rights and wrongs in Albania: An ethnography of agrarian change', Conservation and Society, 2, 19-50.

Dickenson, Donna (2004), 'Consent, commodification and benefit-sharing in genetic research’, Developing World Bioethics, 4, 109-124.

Dietz, Thomas, Elinor Ostrom, and Paul C. Stern (2003), 'The struggle to govern the commons', Science, 302 (5652), 1907-1912.

Dilworth, Richardson (2007), 'Privatization, the world water crisis, and the social contract', PS: Political Science and Politics, 40, 49-54.

Dinar, Ariel (ed.) (2000), The Political Economy of Water Pricing Reforms, New York: Oxford.

Dincer, Oguzhan C. (2007), 'The effects of property rights on economic performance', Applied Economics, 39, 825-837.

Dixon, Kathrine (2007), 'Working with mixed commons/anticommons property: Mobilizing customary land in Papua New Guinea the Melanesian way’, Harvard Environmental Law Review, 31, 219-277.

Dolsak, Nives and Elinor Ostrom (eds.) (2003), The Commons in the New Millennium: Challenges and Adaptations, Cambridge, MA: MIT Press.

Doolittle, Amity A. (2001), 'From village land to “native reserve”: Changes in property rights in Sabah, Malaysia', Human Ecology, 29, 69-98.

Doolittle, Amity A. (2005), Property and Politics in Sabah, Malaysia: Native Struggles over Land Rights, Seattle: University of Washington Press. 
Drahos, Peter (2004), ‘The regulation of public goods', Journal of International Economic Law, 7, 321-339.

Drahos, Peter and Ruth Mayne (eds) (2003), Global Intellectual Property Rights: Knowledge, Access and Development, New York: Palgrave Macmillan.

Drobak, John N. (ed.) (2006), Norms and the Law, Cambridge, MA: Cambridge University Press.

Duany, Julia and Wal Duany (2001), 'War and women in the Sudan: Role change and adjustment to new responsibilities’, Northeast African Studies, 8, 63-82.

Duchrow, Ulrich and Franz J. Hinkelammert (2004), Property for People, Not for Profit: Alternatives to the Global Tyranny of Capital, Geneva: WCC Publications.

Duke, Joshua M. and Ryan P. Jost (2003), 'Promoting mediation in property rights conflicts', Land Economics, 79, 29-37.

Duke, Joshua M. and Lori Lynch (2006), 'Farmland retention techniques: Property rights implications and comparative evaluation', Land Economics, 82, 189213.

Durant, Robert F., Daniel J. Fiorino, and Rosemary O’Leary (eds) (2004), Environmental Governance Reconsidered: Challenges, Choices, and Opportunities, Cambridge, MA: MIT Press.

Durrenberger, E. P. and G. Palsson (1987), ‘Ownership at sea: Fishing territories and access to sea resources', American Ethnologist, 14, 508-522.

Dutfield, Graham (2000), Intellectual Property Rights, Trade and Biodiversity: Seeds and Plant Varieties, London: Earthscan. 
Edney, Julian J. and P. A. Bell (1983), 'The commons dilemma: Comparing altruism, the golden rule, perfect equality of outcomes, and territoriality’, Social Science Journal, 20, 23-33.

Edwards, S. F. (1994), ‘Ownership of renewable ocean resources’, Land Economics, 9, 253-273.

Edwards, S. F. (2001), 'Rent-seeking and property rights formation in the U.S. Atlantic Sea scallop fishery’, Marine Resource Economics, 16, 263-276.

Edwards, S. F. (2003), 'Property rights to multi-attribute fishery resources’, Ecological Economics, 44, 309-323.

Eggertsson, Thráinn (1990), Economic Behavior and Institutions, Cambridge, MA: Cambridge University Press.

Eggertsson, Thráinn (1992), ‘Analyzing institutional successes and failures: A millennium of common mountain pastures in Iceland', International Review of Law and Economics, 12, 423-437.

Eggertsson, Thráinn (1993), 'The economics of institutions: Avoiding the open-field syndrome and the perils of path dependence', Acta Sociologica, 36, 223-237.

Eggertsson, Thráinn (2005), Imperfect Institutions: Possibilities and Limits of Reform, Ann Arbor: University of Michigan Press.

Ellerbusch, Fred (2006), 'Brownfields: Risk, property, and community value’, Local Environment, 11, 559-576.

Ellickson, Robert C. (1991), Order without Law: How Neighbors Settle Disputes, Cambridge, MA: Harvard University Press.

Ellickson, Robert C. (1993), 'Property in land', Yale Law Journal, 102, 1315-1344.

Ellickson, Robert C., Carol M. Rose, and Bruce A. Ackerman (1995), Perspectives on Property Law, Boston, MA: Little, Brown. 
Ellis, Elisabeth (2006), 'Citizenship and property rights: A new look at social contract theory', Journal of Politics, 68, 544-555.

Ely, J. W. (2004), 'Property rights and environmental regulation: The case for compensation', Harvard Journal of Law and Public Policy, 28, 51-60.

Emel, Jacques L. and Elizabeth Brooks (1988), 'Changes in form and function of property rights institutions under threatened resource scarcity', Annals of the Association of American Geographers, 78, 241-252.

Ensminger, Jean (1992), Making a Market: The Institutional Transformation of an African Society, New York: Cambridge University Press.

Epstein, Richard A. (1979), 'Possession as the root of title’, Georgia Law Review, 13, $1221-1243$.

Epstein, Richard A. (1994), 'On the optimal mix of private and common property’, in E. F. Paul, F. D. Miller, and Jeffrey Paul (eds), Property Rights, New York: Cambridge University Press.

Epstein, Richard A. (2002), 'The allocation of the commons: Parking on public roads’, Journal of Legal Studies, 31, S515-S544.

Eyzaguirre, Pablo, Nancy McCarthy, Monica Di Gregorio, and Evan Dennis (2004), 'Property rights, collective action and plant genetic resources', in Ruth Meinzen-Dick and Monica Di Gregorio (eds), Collective Action and Property Rights for Sustainable Development, Washington, DC: International Food Policy Research Institute.

Falcon, W. P. and C. Fowler (2002), 'Carving up the commons-Emergence of a new international regime for germplasm development and transfer', Food Policy, 27, 197-222. 
Falque, Max, Michael De Alessi, and Henri Lamotte (eds) (2002), Marine Resources: Property Rights, Economics, and Environment, New York: Elsevier.

Feder, Gershon and David Feeny (1991), 'Land tenure and property rights: Theory and implications for development policy', World Bank Economic Review, 5, $135-153$.

Feder, Gershon, T. Onchan, Y. Chalamwong, and C. Hangladoran (1988), Land Policies and Form Productivity in Thailand, Baltimore, MD: Johns Hopkins University Press.

Feeny, David (1988), ‘Agricultural expansion and forest depletion in Thailand, 19001975’, in John F. Richards and Richard P. Tucker (eds), World Deforestation in the Twentieth Century, Durham, NC: Duke University Press, pp. 112-143.

Feeny, David (1993), 'The demand for and the supply of institutional arrangements', in Vincent Ostrom, David Feeny, and Hartmut Picht (eds), Rethinking Institutional Analysis and Development, San Francisco, CA: ICS Press, pp. 159-209.

Feeny, David, Fikret Berkes, Bonnie J. McCay, and James M. Acheson (1990), ‘The tragedy of the commons: Twenty-two years later', Human Ecology, 18, 1-19.

Feldman, T. D. and A. E. G. Jonas (2000), 'Sage scrub revolution? Property rights, political fragmentation, and conservation planning in southern California under the federal endangered species act', Annals of the Association of American Geographers, 90, 256-292.

Fernandez, Linda (2006), 'Natural resources, agriculture and property rights', Ecological Economics, 57, 359-373.

Ferreira, Susana (2004), 'Deforestation, property rights, and international trade', Land Economics, 80, 174-193. 
Field, Barry C. (1984), 'The evolution of individual property rights in Massachusetts agriculture, 17th-19th centuries', Northeastern Journal of Agricultural and Resource Economics, 14, 97-109.

Field, Barry C. (1985), 'The optimal commons’, American Journal of Agricultural Economics, 67, 364-367.

Field, Barry C. (1989), 'The evolution of property rights', Kyklos, 42, 319-345.

Fisher, D. E. (2004), 'Rights of property in water: Confusion or clarity?', Environmental and Planning Law Journal, 21, 200-226.

Fitzpatrick, Daniel (2005), ““Best practice” options for the legal recognition of customary tenure', Development and Change, 32, 361-371.

Fitzpatrick, Daniel (2006), 'Evolution and chaos in property rights systems: The Third World tragedy of contested access', Yale Law Journal, 115, 996-1049.

Folke, Carl and Fikret Berkes (1995), 'Mechanisms that link property rights to ecological systems', in Susan Hanna and Mohan Munasinghe (eds), Property Rights and the Environment, Stockholm and Washington, DC: The Beijer International Institute of Ecological Economics and The World Bank.

Fortmann, Louise and John W. Bruce (1988), Whose Trees? Proprietary Dimensions of Forestry, Boulder, CO: Westview Press.

Fox, Jefferson (2002), 'Siam mapped and mapping in Cambodia: Boundaries, sovereignty, and indigenous conceptions of space', Society and Natural Resources, 15, 65-78.

Fox, K. J., R. Q. Grafton, J. Kirkley, and D. Squires (2003), 'Property rights in a fishery: Regulatory change and firm performance', Journal of Environmental Economics and Management, 46, 156-177. 
Francis, Michael (2005), 'Trade and the enforcement of environmental property rights', Journal of International Trade and Economic Development, 14, 281298.

Frey, Bruno S. (1990), 'Institutions matter: The comparative analysis of institutions', European Economic Review, 34, 443-449.

Freyfogle, Eric T. (2002), 'Property rights, the market, and environmental change in 20th century America’, Environmental Law Reporter News and Analysis, 32, 10254-10266.

Freyfogle, Eric T. (2003), The Land We Share: Private Property and the Common Good, Washington, DC: Island Press.

Freyfogle, Eric T. (2003), 'Private property rights in land: An agrarian view’, in N. Wirzba (ed.), The Essential Agrarian Reader: The Future of Culture, Community, and the Land, Lexington: University Press of Kentucky.

Friedman, Alan E. (1971), 'The economics of the common-pool: Property rights in exhaustible resources', UCLA Law Review, 18, 855-873.

Frischmann, Brett M. (2005a), 'An economic theory of infrastructure and commons management', Minnesota Law Review, 89 (4), 917-1030.

Frischmann, Brett M. (2005b), 'Infrastructure commons’, Michigan State Law Review, 89, 121-136.

Frohlich, Norman, Joe Oppenheimer, and Oran Young (1971), Political Leadership and Collective Goods, Princeton, NJ: Princeton University Press.

Furubotn, Eirik G. (1987), 'Privatizing the commons: Comment, with reply by Terry L. Anderson and Peter J. Hill’, Southern Economic Journal, 54, 219-224. 
Furubotn, Eirik G. and Svetozar Pejovich (1972), 'Property rights and economic theory: A survey of recent literature', Journal of Economic Literature, 10, 1137-1162.

Futemma, Celia, Fabio DeCastro, Maria Clara Silva-Forsberg, and Elinor Ostrom (2002), 'The emergence and outcomes of collective action: An institutional and ecosystem approach', Society and Natural Resources, 15, 503-522.

Gadgil, Madhav and Prema Iyer (1989), 'On the diversification of common-property resource use by Indian society’, in Fikret Berkes (ed.), Common Property Resources: Ecology and Community-Based Sustainable Development, London: Belhaven Press, pp. 240-272.

Gaffney, Mason (1992), ‘The taxable surplus in water resources’, Contemporary Policy Issues, 10, 74-82.

Gallardo Fernández, Gloria L. (2002), Communal Land Ownership in Chile: The Agricultural Communities in the Commune of Canela, Norte Chico (16001998), Aldershot: Ashgate.

Gambaro, Antonio (2002), 'Public vs. private land property or complex regimes of rights on land', in M. E. Sánchez Jordan and A. Gambaro (eds), Land Law in Comparative Perspective, New York: Kluwer Law International.

Gardner, Roy and Elinor Ostrom (1991), ‘Rules and games’, Public Choice, 70, 121149.

Gardner, Roy, Elinor Ostrom, and James M. Walker (1990), 'The nature of commonpool resource problems', Rationality and Society, 2, 335-358.

Gaudet, G., M. Moreaux, and S. W. Salant (2002), 'Private storage of common property', Journal of Environmental Economics and Management, 43, 280302. 
Geisler, Charles and Gail Daneker (eds) (2000), Property and Values: Alternatives to Public and Private Ownership, Washington, DC: Island Press.

Gelcich, Stefan, Gareth Edwards-Jones, Michel J. Kaiser, and Elizabeth Watson (2004), 'Using discourses for policy evaluation: The case of marine common property rights in Chile', Society and Natural Resources, 18, 377-391.

Gepts, Paul (2004), 'Who owns biodiversity, and how should the owners be compensated?', Plant Physiology, 134, 1295-1307.

Ghate, Rucha (2004), Uncommons in the Commons: Community Initiated Forest Resource Management, New Delhi: Concept.

Ghate, Rucha and Harini Nagendra (2005), 'Role of monitoring in institutional performance: Forest management in Maharashtra, India', Conservation \& Society, 3, 509-532.

Ghoshal, Sumantra and Peter Moran (1996), 'Bad for practice: A critique of the transaction cost theory', Academy of Management Review, 21, 13-47.

Gibson, Clark C., Krister Andersson, Elinor Ostrom, and Sujai Shivakumar (2005), The Samaritan's Dilemma: The Political Economy of Development Aid, New York: Oxford University Press.

Gibson, Clark C., Fabrice Lehoucq, and John Williams (2002), 'Does privatization protect natural resources? Property rights and forests in Guatemala', Social Science Quarterly, 83, 206-225.

Gibson, Clark C., Margaret A. McKean, and Elinor Ostrom (eds) (2000), People and Forests: Communities, Institutions, and Governance, Cambridge, MA: MIT Press.

Gibson, Clark C., John Williams, and Elinor Ostrom (2005), 'Local enforcement and better forests', World Development, 33 (2), 273-284. 
Gibson, Johanna (2005), Community Resources: Intellectual Property, International Trade and Protection of Traditional Knowledge, Burlington, VT: Ashgate.

Gilles, Jere L. and Keith Jamtgaard (1981), 'Overgrazing in pastoral areas: The commons reconsidered', Sociologia Ruralis, 2, 335-358.

Gimelli, F. (2000), 'Intellectual property rights in agriculture in the light of the debate on biotechnology: Historical evolution and current situation’, Italian Journal of Biochemistry, 49, 41-51.

Gimenez-Maceda, Teresita, Rosario M. Espino, and Shivani Chaudhry (eds) (2001), Marine and Coastal Resources and Community-Based Property Rights: A Philippine Workshop, Quezon City, Philippines: Tanggol Kalikasan, Inc.

Gissurarson, Hannes H. (2000), Overfishing: The Icelandic Solution, London: Institute of Economic Affairs.

Gitter, Donna M. (2004), 'Ownership of human tissue: A proposal for federal recognition of human research participant's property rights in their biological material', Washington and Lee Law Review, 61, 257-346.

Gluck, P. (2002), 'Property rights and multipurpose mountain forest management', Forest Policy and Economics, 4, 125-134.

Godshall, L. E. (2003), ‘Making space for indigenous intellectual property rights under current international environmental law', Georgetown International Environmental Law Review, 15, 497-530.

Godwin, R. Kenneth and W. Bruce Shepard (1977), 'Population issues and commons dilemmas’, Policy Studies Journal, 6, 231-238.

Godwin, R. Kenneth and W. Bruce Shepard (1979), 'Forcing squares, triangles, and ellipses into a circular paradigm: The use of the commons dilemma in 
examining the allocation of common resources', Western Political Quarterly, 32, 265-277.

Goeschl, Timo and Danilo Camargo Igliori (2006), 'Property rights for biodiversity conservation and development: Extractive reserves in the Brazilian Amazon', Development and Change, 37, 427-451.

Goetze, David B. (1987), 'Identifying appropriate institutions for efficient use of common pools’, Natural Resources Journal, 27, 187-191.

Goldsmith, E. N. Hildyard, P. Bunyard, and P. McCully (eds) (1992), Whose Common Future? A Special Issue of The Ecologist, Vol. 22, No.4, July/August 1992, Dorset: Agriculture House.

Gordon, H. Scott (1954), 'The economic theory of a common-property resource: The fishery', Journal of Political Economy, 62, 124-142.

Graff, G. D., S. E. Cullen, K. J. Bradford, D. Zilberman, and A. B. Bennett (2003), 'The public-private structure of intellectual property ownership in agricultural biotechnology’, Nature Biotechnology, 21, 989-995.

Grafton, R. Quentin (2000), 'Governance of the commons: A role for the state?’, Land Economics, 76, 504-517.

Grafton, R. Quentin, Dale Squires, and Kevin J. Fox (2000), 'Private property and economic efficiency: A study of a common-pool resource', Journal of Law and Economics, 43, 679-713.

Grima, A.P. Limo and Fikret Berkes (1989), 'Natural resources: Access, rights to use and management', in Fikret Berkes (ed.), Common Property Resources; Ecology and Community-Based Sustainable Development, London: Belhaven, pp. 33-54. 
Grossi, Paolo (1981), An Alternative to Private Property; Collective Property in the Juridical Consciousness of the Nineteenth Century, Chicago: University of Chicago Press.

Grossman, M. R. (2002), 'Biotechnology, property rights and the environment’, American Journal of Comparative Law, 50, 215-248.

Guadagni, Marco (2002), ‘Trends in customary land property’, in M. E. Sánchez Jordan and A. Gambaro (eds), Land Law in Comparative Perspective, New York: Kluwer Law International.

Guillet, David W. (1992), Covering Ground: Communal Water Management and the State in the Peruvian Highlands, Ann Arbor: University of Michigan Press.

Guillet, David (2000a), 'Reconsidering institutional change: Property rights in northern Spain', American Anthropologist, 102, 713-725.

Guillet, David (2000b), 'Water property rights and resistance to demand management in northwestern Spain', in B. R. Bruns and Ruth Meinzen-Dick (eds), Negotiating Water Rights, New Delhi: Vistaar, pp. 222-244.

Guloksuz, E. (2002), 'Negotiation of property rights in urban land in Istanbul', International Journal of Urban and Regional Research, 26, 462-476.

Gupta, Anil K. (1986), 'Socioecology of stress: Why do common property resource management projects fail?', in National Research Council, Proceedings of the Conference on Common Property Resource Management, Washington, DC: National Academy Press, pp. 305-322.

Gwartney, James D. and Richard Stroup (1988), ‘Communal vs. private property rights', The Freeman, 38, 58-59. 
Haas, Peter M., Robert O. Keohane, and Marc A. Levy (eds) (1993), Institutions for the Earth; Sources of Effective International Environmental Protection, Cambridge, MA: MIT Press.

Haber, Stephen, Armando Razo, and Noel Maurer (2003), The Politics of Property Rights: Political Instability, Credible Commitments, and Economic Growth in Mexico, 1876-1929, New York: Cambridge University Press.

Habron, G. (2003), 'Role of adaptive management for watershed councils', Environmental Management, 31, 29-41.

Haddad, Brent M. (2003), 'Property rights, ecosystem management, and John Locke’s labor theory of ownership', Ecological Economics, 46, 19-31.

Hafer, Catherine (2006), 'On the origins of property rights: Conflict and production in the state of nature', The Review of Economic Studies, 73, 119-143.

Hagedorn, Konrad (2004), 'Property rights reform on agriculture land and Central and Eastern Europe’, Quarterly Journal of International Agriculture, 43, 409-438.

Halkos, G. E. and N. C. Kyriazis (2003), 'Property rights and game-theory implications of satellite communications: The bilateral case of Greece and Russia', European Journal of Law and Economics, 15, 233-250.

Haller, Tobias (2002), 'Common property resource management, institutional change and conflicts in African floodplain wetlands: Presentation of a research project and reflections on institutional change and conflicts', African Anthropologist, 9, 25-35.

Hanisch, Markus (2003), Property Reform and Social Conflict, Aachen, Germany: Shaker Verlag. 
Hanna, Susan (2006), ‘Will structural reform fix fishery management? Commission policy recommendations and the U.S. regional fishery management council system’, Bulletin of Marine Science, 78, 547-562.

Hanna, Susan, Carl Folke, and Karl-Göran Mäler (eds) (1996), Rights to Nature: Ecological, Economic, Cultural, and Political Principles of Institutions for the Environment, Washington, DC: Island Press.

Hanna, Susan and Mohan Munasinghe (eds) (1995a), Property Rights and the Environment, Stockholm and Washington, DC: The Beijer International Institute of Ecological Economics and The World Bank.

Hanna, Susan and Mohan Munasinghe (eds) (1995b), Property Rights in a Social and Ecological Context; Case Studies and Design Applications, Stockholm and Washington, DC: The Beijer International Institute of Ecological Economics and The World Bank.

Hannesson, Rögnvaldur (2005), 'Rights based fishing: Use rights versus property rights to fish', Reviews in Fish Biology and Fisheries, Mäler, 231-241.

Hannesson, Rögnvaldur (2006), The Privatization of the Oceans, Cambridge, MA: MIT Press.

Hardin, Garrett (1968), ‘The tragedy of the commons’, Science, 162, 1243-1248.

Hardin, Garrett (1991), 'The tragedy of the unmanaged commons: Population and the disguises of providence', in R. V. Andelson (ed.), Commons without Tragedy, Savage, MD: Barnes and Noble.

Hardin, Garrett and John Baden (eds) (1977), Managing the Commons, San Francisco, CA: W. H. Freeman. 
Harford, J. D. (2000), 'Methods of pricing common property use and some implications for optimal child-bearing and the social discount rate', Resource and Energy Economics, 22, 103-124.

Hastings, E. M., S. K. Wong, and Megan Walters (2006), 'Governance in a coownership environment: The management of multiple-ownership property in Hong Kong', Property Management, 24, 293-308.

Hayami, Yujiro and Keijiro Otsuka (1993), The Economics of Contract Choice, Oxford: Clarendon Press.

Hazari, B. R. and A. Kumar (2003), ‘Basic needs, property rights and degradation of commons', Pacific Economic Review, 8, 47-56.

Heaney, A. and S. Beare (2002), 'Property rights and externalities in water trade', ACIAR Proceedings, 106, 254-268.

Hedlund, Stefan (2001), 'Property without rights: Dimensions of Russian privatisation', Europe-Asia Studies, 53, 213-238.

Heller, Michael A. (1998), 'The tragedy of the anticommons: Property in the transition from Marx to markets’, Harvard Law Review, 111 (3), 622-688.

Heller, Michael A. (2000), ‘Critical approaches to property institutions: Three faces of private property', Oregon Law Review, 79, 417-434.

Heltberg, Rasmus (2002), 'Property rights and natural resource management in developing countries', Journal of Economic Surveys, 16, 189-214.

Herrera, P. A., G. van Huylenbroek, and R. L. Espinel (2004), 'An application of the contingent valuation method to assess the efficiency of the institutional structure of irrigation property rights: The case of the peninsula of Santa Elena, Ecuador', International Journal of Water Resources Development, 20, $537-552$. 
Herring, Ronald J. (1990), 'Resurrecting the commons: Collective action and ecology', 44 Items, 64-68.

Hess, Charlotte (2007), The Comprehensive Bibliography of the Commons, The Digital Library of the Commons, http://dlc.dlib.indiana.edu/cpr/index.php

Hess, Charlotte and Elinor Ostrom (2003), ‘Ideas, artifacts, and facilities: Information as a common-pool resource', Law and Contemporary Problems, 66, 111-146.

Hess, Charlotte and Elinor Ostrom (eds) (2007), Understanding Knowledge as a Commons: From Theory to Practice, Cambridge, MA: MIT Press.

Higgs, Robert (1996), 'Legally induced technical regress in the Washington salmon fishery’, in L. J. Alston, Thráinn Eggertsson, and Douglass North (eds), Empirical Studies in Institutional Change, New York: Cambridge University Press.

Hilton, Rita (1992), ‘Institutional incentives for resource mobilization: An analysis of irrigation schemes in Nepal', Journal of Theoretical Politics, 4, 283-308.

Hinteregger, Monika and Barbara Pozzo (2002), 'Property and environment', in M. E. Sánchez Jordan and A. Gambaro (eds), Land Law in Comparative Perspective, New York: Kluwer Law International.

Ho, Peter (2001), ‘Who owns China’s land? Property rights and deliberate institutional ambiguity’, China Quarterly, 166, 394-411.

Ho, Peter (2005), Institutions in Transition: Land Ownership, Property Rights, and Social Conflict in China, New York: Oxford University Press.

Hodgson, Geoffrey M. (2003), 'The enforcement of contracts and property rights: Constitutive versus epiphenomenal conceptions of law’, International Review of Sociology, 13, 375-391. 
Hoffman, Irene (2004), 'Access to land and water in the Zamfara Reserve: A case study for the management of common property resources in pastoral areas of West Africa', Human Ecology, 32, 77-105.

Holder, C. D. (2004), 'Changes in structure and cover of a common property pine forest in Guatemala, 1954-1996', Environmental Conservation, 31, 22-29.

Holland, S. P. and M. R. Moore (2003), 'Cadillac Desert revisited: Property rights, public policy, and water-resource depletion', Journal of Environmental Economics and Management, 46, 131-155.

Hotelling, Harold (1931), ‘The economics of exhaustible resources’, Journal of Political Economy, 39, 137-175.

Hotte, Louis (2001), 'Conflicts over property rights and natural-resource exploitation at the frontier', Journal of Development Economics, 66, 1-21.

Hotte, Louis (2005), 'Natural-resource exploitation with costly enforcement of property rights', Oxford Academic Papers, 57, 497-521.

Hsu, S. L. (2003), ‘A two-dimensional framework for analyzing property rights regimes’, University of California Davis Law Review, 36, 813-894.

Hsueh, Vicki (2006), 'Cultivating and challenging the common: Lockean property, indigenous traditionalisms, and the problem of exclusion', Contemporary Political Theory, 5, 193-214.

Hughes, David M. (2001), 'Cadastral politics: The making of community-based resource management in Zimbabwe and Mozambique’, Development and Change, 32, 741-768.

Hulme, D. and M. Murphree (eds) (2001), African Wildlife and Livelihoods: The Promise and Performance of Community Conservation, Oxford, UK: James Currey. 
Husain, Zakir and Rabindra N. Bhattacharya (2004), 'Common pool resources and contextual factors: Evolution of a fishermen's cooperative in Calcutta', Ecological Economics, 50, 201-217.

Hutchinson, Steven and Daniel O’Connor (2005), 'Policing the new commons: Corporate security governance on a mass private property in Canada’, Policing and Society, 15, 125-144.

Igoe, Jim (2004), Conservation and Globalization: A Study of National Parks and Indigenous Communities from East Africa to South Dakota, Belmont, CA: Wadsworth.

Inman, K. and D. M. McLeod (2002), 'Property rights and public interests: A Wyoming agricultural lands study', Growth and Change, 33, 91-114.

Innes, Robert (2000), 'The economics of takings and the compensation when land and its public use value are in private hands', Land Economics, 76, 195-212.

Irrera, F. G., M. J. Oneto, and J. Rabinovich (2001), 'Property rights of public natural resources: A new legal alternative for developing countries', Monographs in Systematic Botany, 84, 304-311.

Jodha, Narpat S. (1990), 'Depletion of common property resources in India: Microlevel evidence', in G. McNicoll and M. Cain (eds), Rural Development and Population: Institutions and Policy, Oxford: Oxford University Press, pp. 261-283.

Jodha, Narpat S. (2007), ‘Common property resources and the rural poor’, in M. Rangarajan (ed.), Environmental Issues in India: A Reader, New Delhi: Pearson Longman, pp. 206-246.

Johannesen, A. B. and A. Skonhoft (2004), 'Property rights and natural resource conservation: A bio-economic model with numerical illustrations from the 
Serengeti-Mara ecosystem’, Environmental and Resource Economics, 28, 469-488.

Johnson, Craig (2004), 'Uncommon ground: The "poverty of history” in common property discourse', Development and Change, 35, 407-434.

Johnson, K. A. and K. C. Nelson (2004), 'Common property and conservation: The potential for effective communal forest management within a national park in Mexico’, Human Ecology, 32, 703-733.

Johnson, Omotunde E. G. (1972), ‘Economic analysis: The legal framework and land tenure systems', Journal of Law and Economics, 15, 259-276.

Johnson, Ronald N. (1985), 'Restraint under open access: Are voluntary incentives sufficient or is coercion required?', American Journal of Agricultural Economics, 67, 373-376.

Johnson, Ronald N. and Gary D. Libecap (1982), ‘Contracting problems and regulation: The case of the fishery', American Economic Review, 72, 10051022.

Johnston, Jason Scott (2000), 'On the commons of common law', in R. E. Meiners and A. P. Morriss (eds), The Common Law and the Environment: Rethinking the Statutory Basis for Modern Environmental Law, New York: Rowman and Littlefield, pp. 211-241.

Jones, Eric C. (2003), ‘Building on Ostrom’s “the rudiments of a theory of the origins, survival, and performance of common-property institutions”, Journal of Ecological Anthropology, 7, 65-72.

Jones, Gareth A. and Peter M. Ward (1998), 'Privatizing the commons: Reforming the ejido and urban development in Mexico', International Journal of Urban and Regional Issues, 22 (1), 76-93. 
Judge, Rebecca P. (2002), 'Restoring the commons: Toward a new interpretation of Locke’s theory of property', Land Economics, 78, 331-338.

Juul, Kristine and Christian Lund (eds) (2002), Negotiating Property in Africa, Portsmouth, NH: Heinemann.

Kadekodi, Gopal K. (2004), Common Property Resource Management: Reflections on Theory and the Indian Experience, New York: Oxford University Press.

Kafumbe, A. L. (2006), 'Women’s property rights and the laws of succession in Uganda: Reform propositions', East African Journal of Peace and Human Rights, 12, 65-90.

Kalinoe, Lawrence Kuna and James Leach (eds) (2004), Rationales of Ownership: Transactions and Claims to Ownership in Contemporary Papua New Guinea, Wantage, UK: Sean Kingston.

Kamara, A., M. Kirk, and B. Swallow (2004), 'Property rights and land use change: Implications for sustainable resource management in Borana, Southern Ethiopia', Journal of Sustainable Agriculture, 25, 45-62.

Kaplowitz, Michael D. (ed.) (2000), Property Rights, Economics, and the Environment, Stamford, CT: JAI Press.

Karp, Larry S. (1992), 'Efficiency inducing tax for a common property oligopoly’, The Economic Journal, 102, 321-332.

Katz, Elizabeth G. (2000), 'Social capital and natural capital: A comparative analysis of land tenure and natural resource management in Guatemala', Land Economics, 76, 114-132.

Kaul, Minoti Chakravarty (1996), Common Lands and Customary Law: Institutional Change in North India over the Past Two Centuries, Oxford: Oxford University Press. 
Kazianga, Harounan and William A. Masters (2006), 'Property rights, production technology, and deforestation: Cocoa in Cameroon’, Agricultural Economics, 35, 19-26.

Kebede, Bereket (2002), 'Land tenure and common pool resources in rural Ethiopia: A study based on fifteen sites', African Development Review, 14, 113-149.

Kendrick, A. (2003), 'The flux of trust: Caribou co-management in northern Canada', Environments, 31, 43-60.

Kennedy, Ronan (2006), ‘International conflicts over plant genetic resources: Future developments?', Tulane Environmental Law Journal, 20, 1-42.

Keohane, Robert O. and Elinor Ostrom (eds) (1995), Local Commons and Global Interdependence: Heterogeneity and Cooperation in Two Domains, London: Sage.

Khan, M. H. (2004), 'Power, property rights and the issue of land reform: A general case illustrated with reference to Bangladesh', Journal of Agrarian Change, 4, 73-106.

Kim, Jongwook and Joseph T. Mahoney (2006), 'How property rights economics furthers the resource-based view: Resources, transaction costs and entrepreneurial discovery', International Journal of Strategic Change Management, 1, 40-52.

Kiser, Larry L. and Elinor Ostrom (1982), 'The three worlds of action: A metatheoretical synthesis of institutional approaches’, in Elinor Ostrom (ed.), Strategies of Political Inquiry, Beverly Hills, CA: Sage, pp. 179-222.

Kissling-Näf, Ingrid and Stefan Kuks (eds) (2004), The Evolution of National Water Regimes in Europe: Transitions in Water Rights and Water Policies, Boston, MA: Kluwer. 
Kleinen, John (2003), 'Access to natural resources for whom? Aquaculture in Nam Dinh, Vietnam’, Maritime Studies (MAST), 2, 39-63.

Kleinsasser, Zachary C. (2005), 'Public and private property rights: Regulatory and physical takings and the public trust doctrine', Boston College Environmental Affairs Law Review, 32, 421-458.

Klooster, Daniel (2000), 'Institutional choice, community, and struggle: A case study of forest co-management in Mexico’, World Development, 28, 1-20.

Knight, F. (1924), 'Some fallacies in the interpretation of social cost', Quarterly Journal of Economics, 38, 582-606.

Kodoth, P. (2001), ‘Gender, family and property rights: Questions from Kerala’s land reforms', Indian Journal of Gender Studies, 8, 291-306.

Kung, J. K. S. (2000), 'Common property rights and land reallocations in rural China: Evidence from a village survey’, World Development, 28, 701-719.

Kurian, Mathew and Ton Dietz (2007), Hydro-Logic: Poverty, Heterogeneity and Cooperation on the Commons, New Delhi: Macmillan India.

Lam, Wai Fung (1996), 'Institutional design of public agencies and coproduction: A study of irrigation associations in Taiwan', World Development, 24, 10391054.

Lam, Wai Fung (1998), Institutions, Engineering Infrastructure, and Performance in the

Governance and Management of Irrigation Systems: The Case of Nepal, San Francisco, CA: ICS Press.

Lanjouw, J. O. and P. I. Levy (2002), 'A study of formal and informal property rights in urban Ecuador', Economic Journal, 112, 986-1019. 
Larson, Bruce A. (ed.) (2003), Property Rights and Environmental Problems, Burlington, VT: Ashgate.

Larson, Bruce A. and Daniel W. Bromley (1990), 'Property rights, externalities, and resource degradation: Locating the tragedy', Journal of Development Economics, 33, 235-262.

Laveleye, Emile de (1985), Primitive Property; Translated from the French of Emile de Laveleye, ed. G. R. L. Marriott, Littleton, CO: F. B. Rothman (Reprint of 1878 edition).

Leach, James (2003), ‘Owning creativity: Cultural property and the efficacy of custom on the Rai Coast of Papua New Guinea’, Journal of Material Culture, 8, 123-143.

Leal, Donald (ed.) (2005), Evolving Property Rights in Marine Fisheries, Lanham, MD: Rowman \& Littlefield.

Lenhart, L. and M. J. Casimir (2001), 'Environment, property resources and the state: An introduction', Nomadic Peoples, 5, 6-20.

Lesorogol, C. K. (2003), ‘Transforming institutions among pastoralists: Inequality and land privatization', American Anthropologist, 105, 531-541.

Levasseur, A. A. (2006), 'The boundaries of property rights: La notion de biens’, American Journal of Comparative Law, 54, 145-166.

Levi, Margaret and Douglass C. North (1982), 'Toward a property rights theory of exploitation', Politics and Society, 11, 315-320.

Levine, B. L. (1986), 'The tragedy of the commons and the comedy of community: The commons in history', Journal of Community Psychology, 14, 81-99. Levine, Ross (2005), 'Law, endowments and property rights', Journal of Economic Perspectives, 19, 61-88. 
Levmore, Saul (2002), ‘Two stories about the evolution of property rights', The Journal of Legal Studies, 31, 421-451.

Lewis, Tracy R. and James Cowens (1983), Cooperation in the Commons: An Application of Repetitious Rivalry, Vancouver: University of British Columbia Press.

Libecap, Gary D. (1989a), Contracting for Property Rights, New York: Cambridge University Press.

Libecap, Gary D. (1989b), 'Distributional issues in contracting for property rights’, Journal of Institutional and Theoretical Economics, 145, 6-24.

Libecap, Gary D. (1995), ‘The conditions for successful collective action’, in Robert O. Keohane and Elinor Ostrom (eds), Local Commons and Global Interdependence: Heterogeneity and Cooperation in Two Domains, London: Sage, pp. 161-190.

Libecap, Gary D. (2007), 'The assignment of property rights on the Western frontier: Lessons for contemporary environmental and resource policy’, Journal of Economic History, 67, 257-291.

Libecap, Gary D., and Steven N. Wiggins (1984), 'Contractual responses to the common pool: Prorationing of crude oil production', American Economic Review, 74, 87-98.

Lichbach, Mark I. (1996), The Cooperator’s Dilemma, Ann Arbor: University of Michigan Press.

Lienhoop, Nele and Douglas C. MacMillan (2007), 'Contingent valuation: Comparing participant performance in group-based approaches and personal interviews’, Environmental Values, 16, 209-232. 
Lindner, Ines and Holger Strulik (2004), 'Why not Africa? Growth and welfare effects of secure property rights', Public Choice, 120, 143-167.

Loehman, Edna and Nir Becker (2006), 'Cooperation in a hydro-geologic commons: New institutions and pricing to achieve sustainability and security', International Journal of Water Resources Development, 22, 603-614.

Lotz, Marianne (2002), 'Colliding worlds: Indigenous rights, traditional knowledge, and plant intellectual property', Business and Professional Ethics Journal, 21, 71-94.

Lu, F. E. (2001), 'The common property regime of the Huaorani Indians of Ecuador implications', Human Ecology, 29, 425-447.

Lueck, Dean (1994), 'Common property as an egalitarian share contract', Journal of Economic Behavior and Organization, 25, 93-108.

Lueck, Dean (1995), 'The rule of first possession and the design of the law', Journal of Law and Economics, 38, 393-436.

Luoga, E. J., E. T. F. Witkowski, and K. Balkwill (2005), 'Land cover and use changes in relation to the institutional framework and tenure of land and resources in Eastern Tanzania Miombo woodlands', Environment, Development and Sustainability, 7, 71-93.

Lynch, Owen J. and Emily Harwell (2002), Whose Natural Resources? Whose Common Good? Towards a New Paradigm of Environmental Justice and the National Interest in Indonesia, Jakarta: Center for International Environmental Law.

Maass, Arthur and Raymond L. Anderson (1986), . . a and the Desert Shall Rejoice: Conflict, Growth, and Justice in Arid Environments, Malabar, FL: R.E. Krieger. 
Macinko, Seth and Daniel W. Bromley (2002), Who Owns America’s Fisheries?, Covelo, CA: Center for Resource Economics.

Macintyre, Martha and Simon Foale (2007), 'Land and marine tenure, ownership, and new forms of entitlement on Lihir: Changing notions of property in the context of a goldmining project', Human Organization, 66, 49-59.

Macpherson, C. B., Anthony Parel, and Thomas Flanagan (1979), Theories of Property: Aristotle to the Present: Essays, Waterloo, Ontario: Wilfred Laurier University Press for the Calgary Institute for the Humanities.

Madulu, Ndalahwa F. (2005), ‘Impacts of population pressure and poverty alleviation strategies on common property resource availability in rural Tanzania’, African Journal of Environmental Assessment and Management, 10, 26-49.

Magrath, William B. (1989), 'The challenge of the commons: The allocation of nonexclusive resources', Washington, DC: The World Bank.

Maine, Henry Sumner (1890), On Early Law and Custom, London: J. Murray.

Maine, Henry Sumner (1963), Ancient Law: Its Connection with the Early History of Society and its Relation to Modern Ideas; With Introduction and Notes by Frederick Pollack, Boston: Beacon Press (reprint of 1861 ed.).

Majumdar, Sumit K. (2007), 'Institutions in transition: Property rights regime changes and the saga of foreign firms in India', India Review, 6, 91-115.

Makdissi, P. (2001), 'Population, natural resources and property rights', Annales d'Economie et de Statistique, 61, 91-104.

Mann, G. (2002), ‘Class consciousness and common property: The international fishermen and allied workers of America', International Labor and Working Class History, 61, 141-160. 
Mansfield, Becky (2001), 'Property regime or development policy? Explaining growth in the U.S. Pacific groundfish fishery', The Professional Geographer, 53, 384-397.

Mansfield, Becky (2004), 'Neoliberalism in the oceans: “Rationalization,” property rights, and the commons question', Geoforum, 35, 313-326.

Manzungu, Emmanuel, Godfrey Chikowore, Dorothy Mushayavanhu, and Dennis Shoko (eds) (2002), Managing Common Property in an Age of Globalisation, Harare, Zimbabwe: Weaver.

Marothia, Dinesh K. (ed.) (2002), Institutionalizing Common Pool Resources, New Delhi: Concept.

Marshall, Graham R. (2004), 'Farmers cooperating in the commons? A study of collective action in salinity management', Ecological Economics, 51, 271286.

Marshall, Graham R. (2005), Economics for Collaborative Environmental Management: Renegotiating the Commons, Bath, UK: Earthscan.

Marshall, Graham R., Simon J. Fritsch, and Robert V. Dulhunty (2005), ‘Catalyzing common property farming for rural sustainability: Lessons from the Furracabad valley’, Australian Agribusiness Review, 13, http://www.agrifood.info/review/2005/Marshall_et_al.html

Marshall, J. (2001), 'Landlords, leaseholders and sweat equity: Changing property regimes in aquaculture', Marine Policy, 25, 335-352.

Martichuski, Diane K. and Paul A. Bell (1991), 'Reward, punishment, privatization, and moral suasion in a commons dilemma', Journal of Applied Social Psychology, 21, 1356-1369. 
Martin, Edward G. (1986), 'Resource mobilization, water allocation, and farmer organization in hill irrigation systems in Nepal’, Ph.D. dissertation, Cornell University.

Marwell, Gerald, and Pamela Oliver (1993), The Critical Mass in Collective Action: A Micro-Social Theory, New York: Cambridge University Press.

Mason, C. F. and S. Polasky (2002), 'Strategic preemption in a common property resource: A continuous time approach', Environmental and Resource Economics, 23, 255-278.

Mason, C. F., Todd Sandler, and Richard Cornes (1988), 'Expectations, the commons, and optimal group size', Journal of Environmental Economics and Management, 15, 99-110.

Matthews, David Ralph (1993), Controlling Common Property: Regulating Canada's East Coast Fishery, Toronto: University of Toronto Press.

Maurer, Georg Ludwig von (1854), Einleitung zur Geschichte der Mark-, Hof Dorfund Stadtverfassung under der Öffentlichen Gewalt, Munich: Verlag von Christian Kaiser.

Maurer, Georg Ludwig von (1856), Geschichte der Markenverfassung in Deutschland, Erlangen: F. Enke.

Maza, Arantza Murillas (2004), ‘Common property under management flexibility: Valuation, optimal exploitation, and regulation', Marine Resource Economics, 19, 173-194.

McCarthy, James (2006), 'Neoliberalism and the politics of alternatives: Community forestry in British Columbia and the United States', Annals of the Association of American Geographers, 96, 84-104. 
McCarthy, John F. (2000), 'The changing regime: Forest property and reformasi in Indonesia', Development and Change, 31, 91-129.

McCay, Bonnie J. (1992), ‘Everyone’s concern, whose responsibility?: The problem of the commons', in S. Ortiz and S. Lees (eds), Understanding Economic Process: Monographs in Economic Anthropology, no. 10, Lanham, MD: University Press of America.

McCay, Bonnie J. (2000), 'Property rights, the commons, and natural resource management', in M. D. Kaplowitz (ed.), Property Rights, Economics, and the Environment, Stamford, CT: JAI Press, pp. 67-82.

McCay, Bonnie J. and James M. Acheson (eds) (1987), The Question of the Commons: The Culture and Ecology of Communal Resources, Tucson, AZ: University of Arizona Press.

McClellan, Traci L. (2001), 'The role of international law in protecting the traditional knowledge and plant life of indigenous peoples', Wisconsin International Law Journal, 19, 249-266.

McCloskey, Donald N. (1976), 'English open fields as behavior towards risk', in Paul J. Uselding (ed.), Research in Economic History 1, Greenwich, CT: JAI Press. McCloskey, Donald N. (1989), 'The open fields of England: Rent, risk, and the rate of interest, 1300-1815', in David W. Galenson (ed.), Markets in History: Economic Studies of the Past, Cambridge: Cambridge University Press.

McCusker, B. (2002), ‘The impact of membership in communal property associations on livelihood in the northern province, South Africa', Geojournal, 56, 113122.

McKean, Margaret A. (1982), 'The Japanese experience with scarcity: Management of traditional common lands', Environmental Review, 6, 63-88. 
McKean, Margaret A. (1992a), 'Management of traditional common lands (Iriaichi) in Japan', in Daniel W. Bromley, et al. (eds), Making the Commons Work: Theory, Practice, and Policy, San Francisco, CA: ICS Press, pp. 63-98.

McKean, Margaret A. (1992b), 'Success on the commons: A comparative examination of institutions for common property resource management', Journal of Theoretical Politics, 4, 247-282.

McKlevay, R. (1985), 'Decentralized regulation of a common property renewable resource industry with irreversible investment', Journal of Environmental Economics and Management, 12, 287-307.

McMahon, Edward T. (2006), 'Sustainability and property rights', Urban Land, 65, 30-33.

McPherson, M. A. and M. L. Nieswiadomy (2000), 'African elephants: The effect of property rights and political stability’, Contemporary Economic Policy, 18, $14-26$.

Mearns, Robin (1996), 'Community, collective action and common grazing: The case of post-Socialist Mongolia', Journal of Development Studies, 32, 297-339.

Meiners, Roger E. and Andrew P. Morriss (2001), 'Property rights in a complex world', Contributions in Economics and Economic History, 224, 179-200.

Meinzen-Dick, Ruth (2007), 'Beyond panaceas in water institutions', Proceedings of the National Academy of Sciences, 104 (39), 15200-15205.

Meinzen-Dick, Ruth S. and Monica Di Gregorio (eds) (2004), Collective Action and Property Rights for Sustainable Development, Washington, DC: International Food Policy Research Institute.

Meinzen-Dick, Ruth, Anna Knox, Frank Place, and Brent Swallow (eds) (2000), Property Rights, Collective Action, and Technologies for Natural Resource 
Management, Washington, DC: Consultative Group on International Agricultural Research.

Meinzen-Dick, Ruth, Anna Knox, Frank Place, and Brent Swallow (eds) (2002), Innovation in Natural Resource Management: The Role of Property Rights and Collective Action in Developing Countries, Baltimore, MD: Johns Hopkins University Press.

Ménard, Claude (ed.) (2004), Transaction Costs and Property Rights, Cheltenham, UK: Edward Elgar.

Menon, Ajit and G. Ananda Vadivelu (2006), 'Common property resources in different agro-climatic landscapes in India', Conservation and Society, 4, 132154.

Merino, Leticia and Jim Robson (eds) (2005a), Managing the Commons: Indigenous Rights, Economic Development and Identity, Mexico: Consejo Civil Mexicano para la Silvicultura Sostenible A.C. et al.

Merino, Leticia and Jim Robson (eds) (2005b), Managing the Commons: Markets, Commodity Chains and Certification, Mexico: Consejo Civil Mexicano para la Silvicultura Sostenible A.C. et al.

Merlo, M., R. Morandini, A. Gabbrielli, and I. Novaco (eds) (1989), Collective Forest Land Tenure and Rural Development in Italy, Rome: Food and Agriculture Organization of the United Nations.

Messerschmidt, Donald A. (1986), 'People and resources in Nepal: Customary resource management systems of the Upper Kali Gandaki', in National Research Council, Proceedings of the Conference on Common Property Resource Management, Washington, DC: National Academy Press, pp. 455480. 
Messerschmidt, Donald A. (ed.) (1993), Common Forest Resource Management: Annotated Bibliography of Asia, Africa, and Latin America, Forests, Trees and People Programme, Rome: Food and Agriculture Organization of the United Nations.

Migot-Adholla, Shem E., Peter Hazell, Benoît Blarel, and Frank Place (1991), 'Indigenous land rights systems in sub-Saharan Africa: A constraint on productivity?’, World Bank Economic Review, 5, 155-175.

Miller, David (1989), ‘The evolution of Mexico’s spiny lobster fishery’, in Fikret Berkes (ed.), Common Property Resources: Ecology and Community-Based Sustainable Development, London: Belhaven Press, pp. 185-198.

Mitchell, Ronald B. (1995), 'Heterogeneities at two levels: States, non-state actors and intentional oil pollution’, in Robert O. Keohane and Elinor Ostrom (eds), Local Commons and Global Interdependence: Heterogeneity and Cooperation in Two Domains, London: Sage, 223-251.

Mixon, F. G. and L. J. Trevino (2003) 'Fugitives as fish: Bounty hunting and exploitation of the commons', Social Science Journal, 40, 657-664.

Mobbs, C. and K. Moore (eds) (2002), Property: Rights and Responsibilities: Current Australian Thinking, Canberra: Land and Water Australia.

Montias, John Michael (1976), The Structure of Economic Systems, New Haven, CT: Yale University Press.

Moran, Emilio and Elinor Ostrom (eds) (2005), Seeing the Forest and the Trees: Human-Environment Interactions in Forest Ecosystems, Cambridge, MA: MIT Press. 
Moser, C. (2004), 'Innovation in natural resource management: The role of property rights and collective action in developing countries', Agricultural Systems, 81, $180-181$.

Moyo, Sam (2005), 'Land and natural resource redistribution in Zimbabwe: Access, equity and conflict', African and Asian Studies, 4, 187-224.

Mukhija, Vinit (2005), 'Collective action and property rights: A planner’s critical look at the dogma of private property', International Journal of Urban and Regional Research, 29, 972-983.

Muñoz Piña, Carlos, A. de Janvry, and E. Sadoulet (2003), 'Recrafting rights over common property resources in Mexico’, Economic Development and Cultural Change, 52, 129-158.

Murphy, Earl Finbar (1977), Nature, Bureaucracy and the Rules of Property: Regulating the Renewing Environment, Amsterdam: North-Holland.

Mutersbaugh, T. (2002), 'Migration, common property, and communal labor: Cultural politics and agency in a Mexican village’, Political Geography, 21, 473-494.

Mwangi, Esther (2006), 'The footprints of history: Path dependence in the transformation of property rights in Kenya’s Maasailand', Journal of Institutional Economics, 2, 157-180.

Mwangi, Esther (2007a), Socioeconomic Change and Land Use in Africa: The Transformation of Property Rights in Maasiland, New York: Palgrave Macmillan.

Mwangi, Esther (2007b), 'Subdividing the commons: Distributional conflict in the transition from collective to individual property rights in Kenya’s Maasailand', World Development, 35, 815-834. 
Nabanoga, Gorettie Nsubuga (2005), Transgressing Boundaries: Gendered Spaces, Species, and Indigenous Forest Management in Uganda, Wageningen, Netherlands: Wageningen University and Research Centre.

Nabli, Mustapha K. and Jeffrey B. Nugent (1989), The New Institutional Economics and Development: Theory and Tunisian Case Studies, Amsterdam: NorthHolland.

Nagendra, Harini (2007), 'Drivers of reforestation in human-dominated forests', Proceedings of the National Academy of Sciences, 104 (39), 15218-15223.

Nagendra, Harini, Mukunda Karmacharya, and Birendra Karna (2005), 'Evaluating forest management in Nepal: Views across space and time’, Ecology and Society, 10, http://www.ecologyandsociety.org/vol10/iss1/art24/

Nahrath, Stéphane (2000), ““Governing wildlife resources”? L’organisation de la chasse en Suisse comme exemple de régimes institutionnels de gestion d'une ressource naturelle', Swiss Political Science Review, 6, 123-158.

National Research Council (2001), Resolving Conflicts Arising from the Privatization of Environmental Data, Washington, DC: National Academy Press.

National Research Council (2002), The Drama of the Commons, Committee on the Human Dimensions of Global Change, Elinor Ostrom, Thomas Dietz, Nives Dolšak, Paul Stern, Susan Stonich, and Elke Weber (eds), Washington, DC: National Academy Press.

Nelson, Gerald C., Virginia Harris, and Steven W. Stone (2001), 'Deforestation, land use, and property rights, empirical evidence from Darién, Panama’, Land Economics, 77, 187-205. 
Nemarundwe, N. and W. Kozanayi (2003), 'Institutional arrangements for water resource use: A case study from southern Zimbabwe', Journal of Southern African Studies, 29, 193-206.

Netting, Robert McC. (1976), 'What Alpine peasants have in common: Observations on communal tenure in a Swiss village', Human Ecology, 4, 135-146.

Netting, Robert McC. (1981), Balancing on an Alp: Ecological Change and Continuity in a Swiss Mountain Community, New York: Cambridge University Press.

Netting, Robert McC. (1993), Smallholders, Householders: Farm Families and the Ecology of Intensive, Sustainable Agriculture, Stanford, CA: Stanford University Press.

Neuburger, M. (2001), 'Property rights in Brazil: The significance of institutional regulations for the vulnerability and survival strategies of smallholder groups', Geographica Helvetica, 56, 34-47.

Newkirk, S. G. (2006), 'Property rights in fisheries', Bulletin of Marine Science, 78, $563-574$.

North, Douglass C. (1990), Institutions, Institutional Change, and Economic Performance, New York: Cambridge University Press.

North, Douglass C. (1993), 'Toward a theory of institutional change', in W. A. Barnett, M. J. Hinich, and N. J. Schofield (eds), Political Economy: Institutions, Competition, and Representation, New York: Cambridge University Press.

North, Douglass C. (2005), Understanding the Process of Economic Change, Princeton, NJ: Princeton University Press. 
North, Douglass C., Terry L. Anderson, and Peter J. Hill (1983), Growth and Welfare in the American Past: A New Economic History, Englewood Cliffs, NJ: Prentice-Hall.

North, Douglass C. and Robert Paul Thomas (1976), The Rise of the Western World: A New Economic History, London: Cambridge University Press.

Nugent, Jeffrey B. and Nicolas Sanchez (1989), 'The efficiency of the mesta reconsidered: A parable’, Explorations in Economic History, 26, 261-284.

Nugent, Jeffrey B. and Nicolas Sanchez (1993), 'Tribes, chiefs, and transhumance: A comparative institutional analysis', Economic Development and Cultural Change, 42, 87-113.

Oakerson, Ronald J. (1992), 'Analyzing the commons: A framework’, in Daniel W. Bromley, et al. (eds), Making the Commons Work: Theory, Practice, and Policy, San Francisco, CA: ICS Press, pp. 41-59.

O’Flaherty, R. M. (2003), 'The tragedy of property: Ecology and land tenure in southeastern Zimbabwe', Human Organization, 62, 178-190.

Okello, Moses (2005), 'Land use changes and human-wildlife conflicts in the Amboseli area, Kenya’, Human Dimensions of Wildlife, 10, 19-28.

Olson, Mancur (1965), The Logic of Collective Action: Public Goods and the Theory of Groups, Cambridge, MA: Harvard University Press.

Ørebech, Peter, Fred Bosselman, Jes Bjarup, David Callies, Martin Chanock, and Hanne Petersen (2005), The Role of Customary Law in Sustainable Development, Cambridge: Cambridge University Press.

Oses-Erasoa, Nuria and Montserrat Viladrich-Grau (2007), 'On the sustainability of common property resources', Journal of Environmental Economics and Management, 53, 393-410. 
Osmundsen, Petter (2002), 'Regulation of common property resources under private information about resource externalities', Resource and Energy Economics, 24, 349-366.

Ostrom, Elinor (1990), Governing the Commons: The Evolution of Institutions for Collective Action, New York: Cambridge University Press.

Ostrom, Elinor (1992), 'The rudiments of a theory of the origins, survival, and performance of common-property institutions', in Daniel W. Bromley, et al. (eds), Making the Commons Work: Theory, Practice, and Policy, San Francisco, CA: ICS Press, pp. 293-318.

Ostrom, Elinor (1993), 'The evolution of norms, rules, and rights', Beijer International Institute of Ecological Economics Discussion Paper Series no. 39, The Digital Library of the Commons, http://dlc.dlib.indiana.edu/archive/00002722/

Ostrom, Elinor (2003), 'How types of goods and property rights jointly affect collective action', Journal of Theoretical Politics, 15, 239-270.

Ostrom, Elinor (2005), Understanding Institutional Diversity, Princeton, NJ: Princeton University Press.

Ostrom, Elinor (2007), ‘A diagnostic approach for going beyond panaceas’, Proceedings of the National Academy of Sciences, 104 (39), 15181-15187.

Ostrom, Elinor, Joanna Burger, Christopher Field, Richard Norgaard, and David Policansky (1999), 'Revisiting the commons: Local lessons, global challenges', Science, 284 (5412), 278-282.

Ostrom, Elinor, Roy Gardner, and James M. Walker (1994), Rules, Games, and Common-Pool Resources, Ann Arbor: University of Michigan Press. 
Ostrom, Elinor, Marco Janssen, and John Anderies 2007. 'Going Beyond Panaceas.' Proceedings of the National Academy of Sciences, 104 (39), 15176-15178.

Ostrom, Elinor and Harini Nagendra (2006), 'Insights on linking forests, trees, and people from the air, on the ground, and in the laboratory', Proceedings of the National Academy of Sciences, 103, 19224-19231.

Ostrom, Vincent (1975), 'Alternative approaches to the organization of public proprietary interests', Natural Resources Journal, 15, 765-789.

Ostrom, Vincent (2007), 'Some developments in the study of market choice, public choice, and institutional choice', in J. Rabin, W. B. Hildreth, and G. Miller (eds), Handbook of Public Administration, New York: CRC Press.

Ostrom, Vincent (2008), The Intellectual Crisis in American Public Administration, 3rd ed., Tuscaloosa: University of Alabama Press.

Ostrom, Vincent and Elinor Ostrom (1977a), 'Public goods and public choices', in E. S. Savas (ed.), Alternatives for Delivering Public Services: Toward Improved Performance, Boulder, CO: Westview Press, pp. 7-49.

Ostrom, Vincent and Elinor Ostrom (1977b), ‘A theory for institutional analysis of common pool problems', in Garrett Hardin and John Baden (eds), Managing the Commons, San Francisco, CA: W. H. Freeman, pp. 157-172.

Otsuka, Keijiro and Frank Place (eds) (2001), Land Tenure and Natural Resource Management: A Comparative Study of Agrarian Communities in Asia and Africa, Baltimore, MD: Johns Hopkins University Press.

Otsuki, T., I. W. Jardie, and E. J. Reis (2002), 'The implications of property rights for joint agriculture-timber productivity in the Brazilian Amazon', Environment and Development Economics, 7, 299-324. 
Oye, Kenneth A. and James H. Maxwell (1995), 'Self-interest and environmental management', in Robert O. Keohane and Elinor Ostrom (eds), Local Commons and Global Interdependence: Heterogeneity and Cooperation in Two Domains, London: Sage, 191-221.

Palmer, Charles (2007), 'The role of leadership in the collective enforcement of community property rights in Indonesia', Society and Natural Resources, 20, 397-413.

Panayotou, Theodore and Peter S. Ashton (1992), Not by Timber Alone: Economics and Ecology for Sustaining Tropical Forests, Washington, DC: Island Press.

Pandit, B. H. and G. B. Thapa (2003), 'A tragedy of non-timber forest resources in the mountain commons of Nepal', Environmental Conservation, 30, 283-292.

Parlee, Brenda, Fikret Berkes, and Teetlit Gwichin Renewable Resources Council (2006), 'Indigenous knowledge of ecological variability and commons management: A case study on berry harvesting from northern Canada', Human Ecology, 34, 515-528.

Pasqual, Joan and Guadalupe Souto (2003), ‘Sustainability in natural resource management', Ecological Economics, 46, 47-59.

Patel, Reena (2006), 'Hindu women’s property rights in India: A critical appraisal', Third World Quarterly, 27, 1255-1268.

Paul, Ellen Frankel, Fred D. Miller, and Jeffrey Paul (eds) (1994), Property Rights, New York: Cambridge University Press.

Payne, G. (2004), 'Land tenure and property rights: An introduction’, Habitat International, 28, 167-179.

Perrings, Charles (2007), ‘Future challenges', Proceedings of the National Academy of Sciences, 104 (39), 15179-15180. 
Peters, Pauline E. (1994), Dividing the Commons: Politics, Policy, and Culture in Botswana, Charlottesville: University Press of Virginia.

Petrzelka, Peggy and Michael M. Bell (2000), 'Rationality and solidarities: The social organization of common property resources in the Imdrhas valley of Morocco’, Human Organization, 59, 343-352.

Pickles, John (2006), ‘Collectivism, universalism, and struggles over common property resources in the “new” Europe', Social Analysis, 50, 178-186.

Pinkerton, Evelyn (ed.) (1989), Co-Operative Management of Local Fisheries: New Directions for Improved Management and Community Development, Vancouver: University of British Columbia.

Pinkerton, Evelyn (1994), 'Local fisheries co-management: A review of international experiences and their implications for salmon management in British Columbia’, Canadian Journal of Fisheries and Aquatic Sciences, 51, 23632378.

Pinto da Silva, Patricia (2004), 'From common property to co-management: Lessons from Brazil’s first maritime extractive reserve', Marine Policy, 28, 419-428. Place, Frank and Peter Hazell (1993), 'Productivity effects of indigenous land tenure systems in sub-Saharan Africa’, American Journal of Agricultural Economics, 75, 10-19.

Platteau, Jean-Philippe (2000), Institutions, Social Norms, and Economic Development, Reading, UK: Harwood Academic.

Plourde, C. G. (1970), ‘Exploitation of common property replenishable natural resources’, Western Economic Journal, 9, 256-266.

Polasky, Stephen, Nori Tarui, Gregory M. Ellis, and Charles F. Mason (2006), 'Cooperation in the commons', Economic Theory, 29, 71-88. 
Posner, Richard A. (1980), 'A theory of primitive society, with special reference to law', Journal of Law and Economics, 23, 1-53.

Poteete, Amy R. (2003), 'Ideas, interests, and institutions: Challenging the property rights paradigm in Botswana', Governance, 16, 527-557.

Poteete, Amy R. and Elinor Ostrom (2004), 'Heterogeneity, group size and collective action: The role of institutions in forest management', Development and Change, 35 (3), 435-461.

Poteete, Amy and Elinor Ostrom (2008), 'Fifteen years of empirical research on collective action in natural resource management: Struggling to build large-N databases based on qualitative research', World Development, 36 (1).

Prasad, B. C. (2003), 'Institutional economics and economic development: The theory of property rights, economic development, good governance and the environment', International Journal of Social Economics, 30, 741-762.

Prasad, B. C. and M. Reddy (2001), ‘Coastal zone management and property rights: Issues for sustainable development in Fiji’, Global Environmental Research, 5, 55-62.

Putterman, Louis (1995), 'Markets, hierarchies, and information: On a paradox in the economics of organization', Journal of Economic Behavior and Organization, 26, 373-390.

Quiggin, John (1988), 'Private and common property rights in the economics of the environment', Journal of Economic Issues, 22, 1071-1087.

Quinn, Claire H., Meg Huby, Hilda Kiwasila, and Jon C. Lovett (2007), 'Design principles and common pool resource management: An institutional approach to evaluating community management in semi-arid Tanzania', Journal of Environmental Management, 84, 100-113. 
Rai, Arti and James Boyle (2007), 'Synthetic biology: Caught between property rights, the public domain, and the commons', PLoS Biology, 5, 389-393.

Rai, M. (2002), 'Genetic resources and intellectual property rights in agricultural perspective', Indian Journal of Pulses Research, 15, 1-18.

Randall, Alan (1975), 'Property rights and social microeconomics', Natural Resources Journal, 15, 729-747.

Randall, Alan (1978), 'Property institutions and economic behavior', Journal of Economic Issues, 12, 1-21.

Randeria, S. (2003), 'Cunning states and unaccountable international institutions: Legal plurality, social movements and rights of local communities to common property resources', Archives Europeennes de Sociologie, 44, 27-60.

Rao, Nitya (2007), ‘Custom and the courts: Ensuring women’s rights to land, Jharkhand, India', Development and Change, 38, 299-319.

Rao, K. Raja Mohan, M. Sabesh Manikandan, and Walter Leaf Filho (2005), 'An overview of the impacts of changes in common property resources management in the context of globalisation: A case study of India', International Journal for Sustainable Development and World Ecology, 12, $471-478$.

Rapoport, Anatol (1988), 'Experiments with N-person social traps: Tragedy of the commons', Journal of Conflict Resolution, 32, 473-488.

Raychaudhuri, Bikash (1980), The Moon and the Net: Study of a Transient Community of Fishermen at Jambudwip, Calcutta: Government of India Press, Anthropological Survey of India. 
Raymond, Leigh (2003), Private Rights in Public Resources: Equity and Property Allocation in Market-Based Environmental Policy, Washington, DC: Resources for the Future.

Reddy, S. P. (2002), 'Communal forests, political spaces: Territorial competition between common property institutions and the state in Guatemala', Space and Polity, 6, 271-278.

Renard, V. (2007), 'Property rights and the "transfer of development rights”: Questions of efficiency and equity', Town Planning Review, 78, 41-60.

Repetto, Robert (1986), Skimming the Water: Rent-Seeking and the Performance of Public Irrigation Systems, Washington, DC: World Resources Institute.

Richard, Alan and Nirvikar Singh (2001), 'No easy exit: Property rights, markets, and negotiations over water', International Journal of Water Resources Development, 17, 409-426.

Ricketts, Martin (2005), 'Poverty, institutions and economics: Hernando De Soto on property rights and economic development', Economic Affairs, 25, 49-51.

Rifkin, Jeremy (2002), 'The treaty initiative to share the genetic commons', Regulatory Affairs Journal, 13, 974-975.

Riley, Angela R. (2000), 'Recovering collectivity: Group rights to intellectual property in indigenous communities', Cardozo Arts and Entertainment Law Journal, 18, 175-191.

Rose, Carol M. (1985), 'Possession as the origin of property', University of Chicago Law Review, 52, 73-88.

Rose, Carol M. (1986), 'The comedy of the commons: Custom, commerce, and inherently public property', University of Chicago Law Review, 53, 711-781. 
Rose, Carol M. (1990), 'Property as storytelling: Perspectives from game theory, narrative theory, feminist theory', Yale Journal of Law and the Humanities, 2, $37-57$.

Rose, Carol M. (1994), Property and Persuasion, Boulder, CO: Westview Press.

Rose-Ackerman, Susan (1977), 'Market models for water pollution control: Their strengths and weaknesses', Public Policy, 25, 383-406.

Rose-Ackerman, Susan (1985), 'Inalienability and the theory of property rights', Columbia Law Review, 85, 931-969.

Ross, Michael L. (2001), Timber Booms and Institutional Breakdown in Southeast Asia, New York: Cambridge University Press.

Roux, Lani and Michael Barry (2001), 'Using video imagery in land tenure information systems: A study of a communal property association in the village of Algeria, South Africa', Geomatica, 55, 47-55.

Roy, K. C. and C. A. Tisdell (2002), 'Property rights in women’s empowerment in rural India: A review’, International Journal of Social Economics, 29, 315334.

Ruddle, Kenneth (1989), 'Traditional sole property rights and modern inshore fisheries management in the Pacific basin', in H. Campbell, K. Menz, and G. Waugh (eds), Economics of Fishery Management in the Pacific Islands Region, Canberra: Australian Centre for International Agricultural Research. Ruddle, Kenneth (1994), 'A guide to the literature on traditional community-based fishery management in the Asia-Pacific tropics’, Rome: Food and Agriculture Organization of the United Nations. 
Ruh, Michael A. and Matthew T. Lockaby (2005), 'Balancing private property rights with "public use": A survey of Kentucky courts' interpretation of the power of eminent domain', Northern Kentucky Law Review, 32, 743-782.

Runge, C. Ford (1981), ‘Common property externalities: Isolation, assurance and resource depletion in a traditional grazing context', American Journal of Agriculture Economics, 63, 595-606.

Runge, C. Ford (1984), ‘The fallacy of privatization’, Journal of Contemporary Studies, 7, 3-17.

Runge, C. Ford (1987), ‘Common property and collective action in economic development', World Development, 14, 623-635.

Runge, C. Ford. and E. Defrancesco (2006), 'Exclusion, inclusion, and enclosure: Historical commons and modern intellectual property’, World Development, 34, 1713-1727.

Ruppert, Evelyn S. (2006), 'Rights to public space: Regulatory reconfigurations of liberty’, Urban Geography, 27, 271-292.

Rushton, Michael (2004), 'Contingent valuation and the public interest in privately owned cultural property', Journal of Arts Management, Law, and Society, 34, 222-234.

Ryan, Alan (1984), Property and Political Theory, New York: Blackwell.

Safrin, Sabrina (2004), 'Hyperownership in a time of biotechnological promise: The international conflict to control the building blocks of life', American Journal of International Law, 98, 641-685.

Sakurai, T. and K. Palanisami (2001), 'Tank irrigation management as a local common property: The case of Tamil Nadu, India', Agricultural Economics, 25, 273-283. 
Sakurai, T. and K. Palanisami (2001), 'Tank irrigation management as a local common property: The case of Tamil Nadu, India', Agricultural Economics, 25, 273-283.

Samuelson, Charles D. (1991), 'Perceived task difficulty, casual attributions, and preferences for structural change in resource dilemmas', Personality and Social Psychology Bulletin, 17, 181-187.

Samuelson, Charles D., D. M. Messick, C. G. Rutte, and H. Wilke (1984), 'Individual and structural solutions to resource dilemmas in two cultures', Journal of Personality and Social Psychology, 47, 94-104.

Sandberg, Audun (1998), 'The analytical importance of property rights to northern resources', in E. Berge and N. C. Stenseth (eds), Law and the Governance of Renewable Resources: Studies from Northern Europe and Africa, Oakland, CA: ICS Press.

Sandberg, Audun (2001), Institutional Challenges for Common Property Resources in the Nordic Countries, Stockholm: Nordregio.

Sandberg, Audun (2007), 'Property rights and ecosystem properties', Land Use Policy, 24, 613-623.

Sandler, Todd (1992), Collective Action: Theory and Applications, Ann Arbor: University of Michigan Press.

Sandler, Todd and Keith Sargent (1995), 'Management of transnational commons: Coordination, publicness, and treaty formation', Land Economics, 68, 249262.

Sandler, Todd and Frederic P. Sterbenz (1990), 'Harvest uncertainty and the tragedy of the commons', Journal of Environmental Economics and Management, 18, $155-167$. 
Saruchera, Munyaradzi (ed.) (2004), Securing Land and Resource Rights in Africa: Pan-African Perspectives, Cape Town, South Africa: Programme for Land and Agrarian Studies.

Sato, Kaori (1987), 'Distribution of the cost of maintaining common property resources', Journal of Experimental Social Psychology, 23, 19-31.

Savas, E. S. (1987), Privatization: The Key to Better Government, Chatham, NJ: Chatham House Publishers.

Sax, Joseph L. (1971), ‘Takings, private property, and public rights’, The Yale Law Journal, 81, 149-186.

Sax, Joseph L. (2002), 'Using property rights to attack environmental protection’, Pace Environmental Law Review, 19, 715-726.

Schaefer, Milner (1957), 'Some considerations of population dynamics and economics in relation to the management of the commercial marine fisheries', Journal of the Fisheries Research Board of Canada, 14, 669-681.

Schelling, Thomas C. (1978), Micromotives and Macrobehavior, New York: W. W. Norton.

Schlager, Edella (1994), 'Fishers’ institutional responses to common-pool resource dilemmas', in Elinor Ostrom, Roy Gardner, and James M. Walker (eds), Rules, Games, and Common-Pool Resources, Ann Arbor: University of Michigan Press, pp. 247-265.

Schlager, Edella, William Blomquist, and Shui Yan Tang (1994), 'Mobile flows, storage, and self-organized institutions for governing common-pool resources', Land Economics, 70, 294-317.

Schlager, Edella and Elinor Ostrom (1992), 'Property rights regimes and natural resources: A conceptual analysis', Land Economics, 68, 249-262. 
Schleyer, C. (2004), 'Economic and ecological transformation processes in East German water management regimes: The role of property rights and governance structures’, Environmental Management, 34, 281-290.

Schmidtz, David and Elizabeth Willott (2003), 'Reinventing the commons: An African case study', U. C. Davis Law Review, 37, 203-232.

Schorr, D. B. (2005), ‘Appropriation as agrarianism: Distributive justice in the creation of property rights', Ecology Law Quarterly, 32, 3-72.

Schotter, Andrew (1981), The Economic Theory of Social Institutions, Cambridge, MA: Cambridge University Press.

Schulz, Ulrich, Wulf Albers, and Ulrich Mueller (eds) (1994), Social Dilemmas and Cooperation, Berlin: Springer-Verlag.

Schworm, William E. (1983), 'Monopsonistic control of a common property renewable resource', Canadian Journal of Economics, 16, 275-287.

Scott, Anthony D. (1955), 'The fishery: The objectives of sole ownership', Journal of Political Economy, 63, 116-124.

Scott, Anthony D. (1983), 'Property rights and property wrongs’, Canadian Journal of Economics, 16, 555-573.

Seabright, Paul (1993), ‘Managing local commons: Theoretical issues in incentive design', Journal of Economic Perspectives, 7, 113-134.

Sekar, C. (2001), 'Externality effects of common property resource degradation’, Indian Journal of Agricultural Economics, 56, 346-357.

Sened, Itai (1991), ‘Contemporary theory of institutions in perspective’, Journal of Theoretical Politics, 3, 379-402.

Sengupta, Nirmal (1991), Managing Common Property: Irrigation in India and the Philippines, New Delhi: Sage. 
Sengupta, Nirmal (1993), User-Friendly Irrigation Designs, New Delhi: Sage.

Sennlaub, Angelika (2005), 'Living with commons — between strain and opportunity:

The sustainability of habitation through communal ownership', GAIA:

Ecological Perspectives for Science and Society, 14, 323-332.

Sethi, Rajiv and E. Somanathan (1996), 'The evolution of social norms in common property resource use', American Economic Review, 86, 766-788.

Sgard, Jérôme (2004), 'Are there such things as international property rights?', World Economy, 27, 387-401.

Shams, Numa and Mahfuzuddin Ahmed (2000), 'Common and private property linkages in the low-land forest-fishery-farming systems of Cambodia', Journal of Sustainable Agriculture, 15, 59-88.

Sheehan, J. (2001), 'Indigenous property rights and river management’, Water Science and Technology, 43, 235-242.

Shivakoti, Ganesh P., Douglas Vermillion, Wai-Fung Lam, Elinor Ostrom, Ujjwal Pradhan, and Robert Yoder (eds) (2005), Asian Irrigation in Transition: Responding to Challenges, Thousand Oaks, CA: Sage.

Shivakoti, Ganesh P. and Elinor Ostrom (eds) (2002), Improving Irrigation Governance and Management in Nepal, Oakland, CA: ICS Press.

Shotton, Ross (ed.) (2001a), Case Studies on the Allocation of Transferable Quota Rights in Fisheries, Rome: Food and Agriculture Organization of the United Nations.

Shotton, Ross (ed.) (2001b), Case Studies on the Effects of Transferable Fishing Rights on Fleet Capacity and Concentration of Quota Ownership, Rome: Food and Agriculture Organization of the United Nations. 
Sikor, Thomas (2001), 'The allocation of forestry land in Vietnam: Did it cause the expansion of forests in the northwest?', Forest Policy and Economics, 2, 1-11.

Sikor, Thomas (2004a), 'The commons in transition: Agrarian and environmental change in Central and Eastern Europe', Environmental Management, 34, 270280.

Sikor, Thomas (2004b), 'Conflicting concepts: Contested land relations in northwestern Vietnam', Conservation and Society, 2, 75-95.

Singh, Chatrapati (1986), Common Property and Common Poverty: India's Forests, Forest Dwellers, and the Law, Oxford: Oxford University Press.

Singh, H. (2004), 'Intellectual property rights (IPR) issues in horticulture: An Indian scenario with particular reference to medicinal plants', Acta Horticulturae, 662, 465-470.

Singh, J. P. (2001), 'From POTS to E-commerce: What have the developing countries learnt about property rights over the last 50 years?', Prometheus, 19, 347-362.

Singh, Katar (1994), Managing Common Pool Resources: Principles and Case Studies, New Delhi: Oxford University Press.

Singh, Katar and Vishwa Ballabh (1996), Cooperative Management of Natural Resources, New Delhi: Sage.

Singh, Nandita (2006), 'Indigenous water management systems: Interpreting symbolic dimensions in common property resource regimes', Society and Natural Resources, 19, 357-366.

Singh, V. K., A. Suresh, D. C. Gupta, and R. C. Jakhmola (2005), 'Common property resources, rural livelihood, and small ruminants in India: A review', Indian Journal of Animal Sciences, 75, 1027-1036. 
Singleton, Sara and Michael Taylor (1992), 'Common property, collective action and community', Journal of Theoretical Politics, 4, 309-324.

Sinn, Hans-Werner (1984), 'Common property resources, storage facilities and ownership structures: A Cournot model of the oil market’, Economica, 51, 235-252.

Sipponen, M., K. Muje, T. J. Marjomaki, P. Valkeajarvi, and J. Karjalainen (2006), 'Interlocked use of inland fish resources: A new management strategy under private property rights', Fisheries Management Ecology, 13, 299-307.

Siy, Robert Y., Jr. (1982), Community Resource Management: Lessons from the Zanjera, Quezon City: University of the Philippines Press.

Slaughter, R. A. and J. D. Wiener (2007), 'Water, adaptation, and property rights on the Snake and Klamath Rivers', Journal of the American Water Resources Association, 43 (2), 308-321.

Smajgl, Alex and Silva Larson (eds) (2007), Sustainable Resource Use: Institutional Dynamics and Economics, Sterling, VA: Earthscan.

Smets, Henri (2004), 'The right to water as an enforceable right', Environmental Policy and Law, 34, 84-85.

Smith, Henry E. (2000), 'Semicommon property rights and scattering in the open fields', Journal of Legal Studies, 29, 131-169.

Smith, R. J. (1981), 'Resolving the tragedy of the commons by creating private property rights in wildlife', CATO Journal, 1, 439-468.

Smith, Vernon L. (1968), 'Economics of production from natural resources', American Economic Review, 58, 409-431. 
Snidal, Duncan (1985), 'Coordination versus prisoners dilemma: Implications for international cooperation and regimes', American Political Science Review, 79, 923-947.

Sorger, Gerhard (2005), ‘A dynamic common property resource problem with amenity value and extraction costs', International Journal of Economic Theory, 1, 3-20.

Soroos, Marvin S. (2001), 'The evolution of global commons’, in Global Environmental Policies: Institutions and Procedures, New York: Palgrave, pp. 39-65.

Sowerwine, Jennifer C. (2004), 'Territorialisation and the politics of highland landscapes in Vietnam: Negotiating property relations in policy, meaning and practice', Conservation and Society, 2, 97-136.

Spier, V. E. (2001), 'Finders’ keepers: The dispute between developed and developing countries over ownership of property rights in genetic material', Widener Law Symposium Journal, 7, 203-226.

Sproule-Jones, Mark (1982), 'Public choice theory and natural resources: Methodological explication and critique', American Political Science Review, 76, 790-804.

Srinivas, Krishna Ravi (2006), ‘Intellectual property rights and bio commons: Open source and beyond', International Social Science Journal, 188, 319-334.

Sserunkuuma, Dick and Kent Olson (2001), 'Private property rights and overgrazing: An empirical assessment of pastoralists in Nyabushozi County, Western Uganda,' Economic Development and Cultural Change, 49, 769-792.

Starrett, D. A. (2003), 'Property rights, public goods and the environment', Handbook in Economics, 20, 97-123. 
Steele, Scott R. (2001), 'Property regimes as information regimes: Efficiency and economies of joint production', Environmental and Resource Economics, 18, 317-337.

Steelman, Toddi A. and Richard L. Wallace (2001), 'Property rights and property wrongs: Why context matters in fisheries management', Policy Sciences, 34, 357-379.

Stern, P. C. (1978), 'When do people act to maintain common resources: A reformulated psychological question for our times', International Journal of Psychology, 13, 149-158.

Stevenson, Glenn G. (1991), Common Property Economics: A General Theory and Land Use Applications, Cambridge: Cambridge University Press.

Stewart, James M. and Peter D. Callagher (2003), 'New Zealand fisheries management: Changes in property rights structure and implications for sustainability’, Sustainable Development, 11, 69-76.

Stolzenberg, Nomi Maya (2000), ‘The culture of property’, Daedalus, 129, 169-192.

Strappazzon, Loris, et al. (2003), 'Efficiency of alternative property right allocations when farmers produce multiple environmental goods under the condition of economies of scope', Australian Journal of Agricultural and Resource Economics, 47 (1), 1-27.

Sugden, Robert (1986), The Economics of Rights, Cooperation, and Welfare, Oxford: Basil Blackwell.

Sugiah, Siti, Machfud Mugniesyah, and Mizuno Kosuke (2007), 'Access to land in Sundanese community: A case study of upland peasant households in Kemang village, West Java, Indonesia’, South East Asian Studies, 44, 519-544. 
Sundberg, Jeffrey O. (2006), 'Private provision of a public good: Land trust membership', Land Economics, 82, 353-366.

Suryanata, K. and K. N. Umemoto (2003), 'Tension at the nexus of the global and local: Culture, property, and marine aquaculture in Hawai'i', Environment and Planning 8, 35, 199-213.

Susilowati, Indah, Norman Bartoo, Ishak Haji Omar, Yongil Jeon, K. Kuperan, Dale Squires, and Niels Vestergaard (2005), 'Productive efficiency, property rights, and sustainable renewable resource development in the mini-purse seine fishery of the Java Sea', Environment and Development Economics, 10, 837859.

Svensson, Tom G. (2002), 'Indigenous rights and customary law discourse: Comparing the Nisga'a and the Sami’, Journal of Legal Pluralism and Unofficial Law, 47, 1-36.

Swallow, Brent M. and Daniel W. Bromley (1994), 'Co-management or no management: The prospects for internal governance of common property regimes through dynamic contracts', Oxford Agrarian Studies, 22, 3-16.

Swallow, Brent M., Dennis P. Garrity, and Meine van Noordwijk (2002), 'The effects of scales, flows and filters on property rights and collective action in watershed management', Water Policy, 3, 457-474.

Swaney, James A. (1990), ‘Common property, reciprocity, and community’, Journal of Economic Issues, 24, 451-462.

Swaney, James A. (2003), 'Are democracy and common property possible on our small Earth?', Journal of Economic Issues, 37, 259-288. 
Swierzbinski, Joseph (1988), ‘When more isn’t better: Information and commonproperty resources’, Mathematical and Computational Modelling, 11, 899902.

Swanson, Timothy and Timo Goschl (2000), 'Property rights issues involving plant genetic resources: Implications of ownership for economic efficiency’, Ecological Economics, 32, 75-92.

Tang, Shui Yan (1992), Institutions and Collective Action: Self-Governance in Irrigation, San Francisco, CA: ICS Press.

Tang, Shui Yan (1994), 'Building community organizations: Credible commitment and the new institutional economics’, Human Systems Management, 13, 221232.

Tanner, Adrian (2007), 'On understanding too quickly: Colonial and postcolonial misrepresentation of indigenous Fijian land tenure’, Human Organization, 66, $69-77$.

Tansey, Geoff (2002), 'Patenting our food future: Intellectual property rights and the global food system', Social Policy and Administration, 36, 575-592.

Tarui, Nori (2007), 'Inequality and outside options in common-property resource use', Journal of Development Economics, 83, 214-239.

Taylor, Michael and Sara Singleton (1995a), Anarchy and Cooperation, London: Wiley.

Taylor, Michael and Sara Singleton (1995b), ‘The communal resource: Transaction costs and the solution of collective action problems', Politics and Society, 21, 34-46.

Taylor, P. L. (2003), 'Reorganization or division? New strategies of community forestry in Durango, Mexico’, Society and Natural Resources, 16, 643-661. 
Taylor, W. E. (2004), 'Property rights and responsibilities? The case of Kenya', Habitat International, 28, 275-287.

Teng, Jimmy (2000), ‘Endogenous authoritarian property rights’, Journal of Public Economies, 77, 81-95.

Thé, Ana Paula Glinfskoi and Nivaldo Nordi (2006), 'Common property resource system in a fishery of the Sao Francisco River, Minas Gerias, Brazil’, Human Ecology Review, 13, 1-10.

Thompson, Carol B. (2004), 'International law of the sea/seed: Public domain versus private commodity’, Natural Resources Journal, 44, 841-866.

Thompson, Dale B. (2006), 'Of rainbows and rivers: Lessons for telecommunications spectrum policy from transitions in property rights and commons in water law’, Buffalo Law Review, 54, 157-210.

Thomson, James T. (1977), 'Ecological deterioration: Local-level rule-making and enforcement problems in Niger', in Michael H. Glantz (ed.), Desertification: Environmental Degradation in and around Arid Lands, Boulder, CO: Westview Press, pp. 57-79.

Thomson, James T., David Feeny, and Ronald Oakerson (1992), 'Institutional dynamics: The evolution and dissolution of common-property resource management', in Daniel W. Bromley, et al. (eds), Making the Commons Work: Theory, Practice, and Policy, San Francisco, CA: ICS Press, pp. 129-160.

Tisdell, Clem (2004), 'Property rights in non-captive wildlife and biodiversity conservation', International Journal of Global Environmental Issues, 4, 195208.

Toly, Noah (2005), 'A tale of two regimes: Instrumentality and commons access’, Bulletin of Science, Technology and Society, 25, 26-36. 
Tran, Thanh Ngoc (2005), From Legal Acts to Village Institutions and Forest Use Practices: Effects of Devolution in the Central Highlands of Vietnam, Germany: Shaker Verlag.

Trommetter, Michel (2005), 'Biodiversity and international stakes: A question of access’, Ecological Economics, 53, 573-583.

Tubtim, Nattaya and Philip Hirsch (2005), 'Common property as enclosure: A case study of a backswamp in southern Laos', Society and Natural Resources, 18, 41-60.

Tucker, Catherine, J. C. Randolph, and E. Castellanos (2007), 'Institutions, biophysical factors and history: An integrative analysis of private and common property forests in Guatemala and Honduras’, Human Ecology, 35, 259-274.

Tyer, C. B. (2000), 'Public needs vs. private loss: Land use regulation and property rights', International Journal of Public Administration, 23, 479-505.

Ullmann-Margalit, Edna (1978), The Emergence of Norms, Oxford: Oxford University Press.

Umbeck, John R. (1981a), 'Might makes rights: A theory of the formation and initial distribution of property rights', Economic Inquiry, 20, 38-59.

Umbeck, John R. (1981b), A Theory of Property Rights: With Application to the California Gold Rush, Ames: Iowa State University Press.

Unruh, Jon D. (2002), 'Poverty and property rights in the developing world: Not as simple as we would like', Land Use Policy, 19, 275-276.

Unruh, Jon D. (2006), 'Land tenure and the “evidence landscape” in developing countries’, Annals of the Association of American Geographers, 96, 754-772. 
Unruh, Jon, Lisa Cligget, and Ron Hay (2005), ‘Migrant land rights reception and “clearing to claim” in sub-Saharan Africa: A deforestation example from southern Zambia’, Natural Resources Forum, 29, 190-198.

Vail, David and Lars Hultkrantz (2000), 'Property rights and sustainable nature tourism: Adaptation and mal-adaptation in Dalarna (Sweden) and Maine (USA)', Ecological Economics, 35, 223-242.

vanderWalt, A. J. (2001), 'Dancing with codes: Protecting, developing and deconstructing property rights in a constitutional state', South African Law Journal, 118, 258-311.

van Erp, S. (2003), 'Civil and common property law: Caveat comparator-the value of legal historical-comparative analysis', European Review of Private Law, 11, 394-411.

Van Overwalle, Geertrui (2005), 'Protecting and sharing biodiversity and traditional knowledge: Holder and user tools’, Ecological Economics, 53, 585-607.

Varughese, George and Elinor Ostrom (2001), 'The contested role of heterogeneity in collective action: Some evidence from community forestry in Nepal', World Development, 29 (5), 747-765.

Veeman, T. S. and J. Politylo (2003), 'The role of institutions and policy in enhancing sustainable development and conserving natural capital', Environment, Development and Sustainability, 5, 317-332.

Vincent, Linden (1995), Hill Irrigation: Water and Development in Mountain Agriculture, London: Overseas Development Institute.

Wade, Robert (1992), 'Common-property resource management in South Indian villages', in Daniel W. Bromley, et al. (eds), Making the Commons Work: Theory, Practice, and Policy, San Francisco, CA: ICS Press, pp. 207-228. 
Wade, Robert (1994), Village Republics: Economic Conditions for Collective Action in South India, San Francisco, CA: ICS Press.

Waldron, Jeremy (1988), The Right to Private Property, Oxford: Clarendon.

Webb, Edward and Ganesh Shivakoti (eds) (2007), Decentralization, Forests and Rural communities: Policy Outcomes in South and Southeast Asia, New Delhi: Sage.

Webster, Christopher J. (2002), 'Property rights and the public realm: Gates, green belts, and gemeinschaft', Environment and Planning B, 29, 397-412.

Weinstein, Martin S. (2000), 'Pieces of the puzzle: Solutions for community-based fisheries management from native Canadians, Japanese cooperatives, and common property', Georgetown International Environmental Law Review, 12, $375-412$.

Weitzman, Martin (1974), 'Free access vs. private ownership as alternative systems for managing common property’, Journal of Economic Theory, 8, 225-234.

Welch, W. P. (1983), 'The political feasibility of full ownership property rights: The cases of pollution and fisheries', Policy Sciences, 16, 165-80.

Westerland, K. 2007. 'Nepal's community forestry program: Another example of the tragedy of the commons or a realistic means of balancing indigenous needs with forestry conservation?', Colorado Journal of International Environmental Law and Policy, 18, 189-216.

Whalley, John and Ben Zissimos (2001), 'What could a world environmental organization do?', Global Environmental Politics, 1, 29-34.

Wiersma, Lindsey L. (2005), 'Indigenous lands as cultural property: A new approach to indigenous land claims', Duke Law Journal, 54, 1061-1088. 
Wiersum, K. F., R. Singhal, and C. Benneker (2004), 'Common property and collaborative forest management: Rural dynamics and evolution in community forestry regimes', Forests, Trees and Livelihoods, 14, 281-29.

Wilke, Henk (1992), 'Greed, efficiency and fairness in resource management situations', European Review of Social Psychology, 2, 165-187.

Williamson, Sima, David Brunckhorst, and Gerard Kelly (2003), Reinventing the Common: Cross-Boundary Farming for a Sustainable Future, Sydney: Federation.

Wilson, Douglas Clyde, Jesper Raakjaer Nielsen, and Poul Degnbol (eds) (2003), The Fisheries Co-Management Experience: Accomplishments, Challenges and Prospects, London: Kluwer.

Wilson, James A., James M. Acheson, Mark Metcalfe, and Peter Kleban (1994), 'Chaos, complexity, and community management of fisheries', Marine Policy, 18, 291-305.

Wilson, James A. and Lloyd M. Dickie (1995), 'Parametric management of fisheries: An ecosystem-social approach', in Susan Hanna and Mohan Munasinghe (eds), Property Rights in a Social and Ecological Context: Case Studies and Design Applications, Stockholm and Washington, DC: The Beijer International Institute of Ecological Economics and The World Bank.

Wilson, James A., J. French, P. Kleban, S. R. Mckay, and R. Townsend (1991), 'Chaotic dynamics in a multiple species fishery: A model of community predation’, Ecological Modelling, 58, 303-322.

Wilson, James, Liying Yan, and Carl Wilson (2007), 'The precursors of governance in the Maine lobster fishery', Proceedings of the National Academy of Sciences, 104 (39), 15212-15217. 
Wily, Liz Alden (2000), 'The democratization of forest management in eastern and southern Africa', International Forestry Review, 2, 287-294.

Wily, Liz Alden (2002), 'The political economy of community forestry in Africa: Getting the power relations right’, Forests, Trees and People Newsletter, 46, $4-12$.

Wily, Liz Alden and Sue Mbaya (2001), Land, People, and Forests in Eastern and Southern Africa at the Beginning of the 21st Century: The Impact of Land Relations on the Role of Communities in Forest Future, Nairobi, Kenya: IUCN- EARO.

Wollenberg, Eva, David Edmunds, and Jon Anderson (eds) (2001), Accommodating Multiple Interests in Local Forest Management: Special Issue of the International Journal of Agricultural Resources, Governance and Ecology, vol. 1, nos. 3/4, Oxford, UK: Inderscience Enterprises.

Wollenberg, Eva, Leticia Merino, Arun Agrawal, and Elinor Ostrom (2007), 'Fourteen years of monitoring community-managed forests: Learning from IFRI’s experience', International Forestry Review, 9 (2), 670-684.

Wunderlich, Gene (1974), 'Property rights and information', The Annals of American Academy of Political and Social Science, 412, 80-96.

Wunderlich, Gene and W. L. Gibson (eds) (1972), Perspectives of Property, College Station: Pennsylvania State University, Institute for Research on Land and Water Resources.

Yablon, M. (2004), 'Property rights and sacred sites: Federal regulatory responses to American Indian religious claims on public land', Yale Law Journal, 113, $1623-1662$. 
Yandle, Bruce (ed.) (1995), Land Rights: The 1990’s Property Rights Rebellion, Lanham, MD: Rowman \& Littlefield.

Yandle, Tracy (2003), 'The challenge of building successful stakeholder organizations: New Zealand’s experience in developing a fisheries comanagement regime', Marine Policy, 27 (2), 179-192.

Young, Oran R. (1982), Resource Regimes: Natural Resources and Social Institutions, Berkeley: University of California Press.

Young, Oran R. (1989), International Cooperation: Building Regimes for Natural Resources and the Environment, Ithaca, NY: Cornell University Press.

Zwarteveen, Margreet and Ruth Meinzen-Dick (2001), 'Gender and property rights in the commons: Examples of water rights in South Asia', Agriculture and Human Values, 18, 11-25. 
Table 1

Bundles of Rights Associated with Positions

\begin{tabular}{llllll}
\hline & Owner & Proprietor & Claimant & $\begin{array}{l}\text { Authorized } \\
\text { User }\end{array}$ & $\begin{array}{l}\text { Authorized } \\
\text { Entrant }\end{array}$ \\
\hline Access & $\mathrm{X}$ & $\mathrm{X}$ & $\mathrm{X}$ & $\mathrm{X}$ & $\mathrm{X}$ \\
Withdrawal & $\mathrm{X}$ & $\mathrm{X}$ & $\mathrm{X}$ & $\mathrm{X}$ & \\
Management & $\mathrm{X}$ & $\mathrm{X}$ & $\mathrm{X}$ & $\mathrm{X}$ & \\
Exclusion & $\mathrm{X}$ & $\mathrm{X}$ & & & \\
Alienation & $\mathrm{X}$ & & & & \\
\hline
\end{tabular}

Source: E. Ostrom and Schlager (1996, p. 133). 